\title{
Cracking and load-deformation behavior of fiber reinforced concrete: Influence of testing method
}

Paegle, leva; Minelli, Fausto; Fischer, Gregor

Published in:

Cement and Concrete Composites

Link to article, DOI:

10.1016/j.cemconcomp.2016.06.012

Publication date:

2016

Document Version

Peer reviewed version

Link back to DTU Orbit

Citation (APA):

Paegle, I., Minelli, F., \& Fischer, G. (2016). Cracking and load-deformation behavior of fiber reinforced concrete: Influence of testing method. Cement and Concrete Composites, 73, 147-163.

https://doi.org/10.1016/j.cemconcomp.2016.06.012

\section{General rights}

Copyright and moral rights for the publications made accessible in the public portal are retained by the authors and/or other copyright owners and it is a condition of accessing publications that users recognise and abide by the legal requirements associated with these rights.

- Users may download and print one copy of any publication from the public portal for the purpose of private study or research.

- You may not further distribute the material or use it for any profit-making activity or commercial gain

- You may freely distribute the URL identifying the publication in the public portal

If you believe that this document breaches copyright please contact us providing details, and we will remove access to the work immediately and investigate your claim. 


\section{Cracking and load-deformation behavior of fiber reinforced concrete: influence of testing method}

Ieva Paegle a , Fausto Minelli ${ }^{\mathrm{b}}$, Gregor Fischer ${ }^{\mathrm{c}}$

a Department of Civil Engineering, Technical University of Denmark, Brovej 118, 2800 Kgs.Lyngby, Denmark. Email: ievap@byg.dtu.dk

b Department of Civil Engineering, Architecture, Environment, Land Planning and Mathematics, University of Brescia, Via Branze 43, 25123 Brescia, Italy. Email: fausto.minelli@unibs.it

c Department of Civil Engineering, Technical University of Denmark, Brovej 118, 2800 Kgs.Lyngby, Denmark. Email: gf@byg.dtu.dk

Corresponding author: Ieva Paegle a , tel. +45 45251700

\section{ABSTRACT}

The characterization of the tensile behavior of cementitious materials has been a longstanding research topic and a general consensus on how to accomplish this task has not yet been reached. Many standardized tests are available but each with different test set-up and prescriptions on the definition of measured and derived parameters, including toughness, elastic properties and strength. This paper discusses a number of test procedures for selected material properties including tension and flexure. A comparative experimental study was carried out using two distinct fiber reinforced cementitious composites with strain hardening and strain softening behavior. Digital Image Correlation was utilized in the experimental program to detect and quantify the formation of cracks. Results show that the different test methodologies valuate specific aspects of material performance. The outcome of these evaluation procedures is compared and critically analyzed.

Keywords: fiber reinforcement; testing; material characterization; strain hardening; toughness; digital image correlation 


\section{INTRODUCTION}

The description of testing and characterization procedures for fiber reinforced cementitious composites (FRCC) in the recent publication of the fib Model Code 2010 [1] emphasizes the significance of defining suitable material parameters, including the post-peak tensile behavior of FRCC, to be utilized in the design of structural members. Dimensioning and verifying the load capacity of any structural element made with randomly distributed fibers, with or without traditional reinforcement, requires the determination of equivalent elastic postcracking strengths of the FRCC material. There are many standard methods available to derive the post-cracking response of FRCC. Among several tests for characterizing FRCC in tension, it is possible to distinguish three main test categories, characterized by different setup and stress fields generated:

- Uni-axial tension tests, with a prescribed single crack or possible multiple cracking;

- Flexural beam tests, performed on notched or un-notched prisms, under three or fourpoint loading;

- Flexural plate tests (square panel with continuous support or round panel with 3 point supports);

In the first group of test methods, the single-crack notched [2] coupon test and the dog-bone test $[3,4]$ are intended to determine the local and global tensile behavior of a FRCC material with special emphasis on strain-hardening materials. In the second group of tests, among many different beam types and loading configurations, the most common are the three or four-point bending test, with or without notch. The notched three-point bending test according to EN 14651 [5] and the un-notched four-point bending test according to ASTM C1609 [6] and DAfStb [7] are the most often utilized. In the third group of tests, the round determinate panel (RDP) according to ASTM C1550 [8] was developed especially to measure the energy absorption, utilized in sprayed fiber reinforced concrete applications. A 
recent publication suggests expanding the utilization of the RDP test to a mechanical characterization of the material [9], implementing set-up through closed-loop control and crack width measurements.

To evaluate advantages, disadvantages and specific features of different test methodologies, experimental tests on two FRCC materials were conducted including two tensile tests, two types of beam tests and a round panel test. Furthermore, in the case of ASTM C 1609 beams and ASTM C 1550 round panels, the influence of alternative specimen geometries was also considered to investigate any influence of specimen size and slenderness on the results of the material characterization.

The consistency and reliability of the test results were evaluated in terms of scatter of the test results, stress disturbance (compared to the stress filed according to beam theory) due to concentrated load and notch, influence of fiber orientation, fiber type, fiber properties as well as specimen size.

The objective of this paper is to investigate the suitability of the main types of test methods to accurately characterize FRCC materials in tension, including not only common tension softening materials, but also materials with a hardening response. Furthermore, the usefulness of the obtained results with respect to structural design is evaluated.

\section{MATERIAL DESCRIPTIONS AND EXPERIMENTAL METHODS}

The two types of materials used in this investigation were a steel fiber reinforced concrete (SFRC) with a softening behavior in tension and a representative strain hardening material known as Engineered Cementitious Composite (ECC). In addition to the standardized test methods above mentioned, a digital image correlation (DIC) technique was used in the experimental program to continuously measure specimen deformations and to detect and 
quantify the formation of cracks. The test methods are divided in three categories including 1) uniaxial tensile tests, 2) flexural beam tests, and 3) flexural plate tests.

\section{Materials}

The strain hardening ECC was reinforced with $2 \%$ by volume polyvinyl alcohol (PVA) fibers, equivalent to $26 \mathrm{~kg} / \mathrm{m}^{3}$. The ECC matrix consisted of $856 \mathrm{~kg} / \mathrm{m}^{3} \mathrm{fly}$ ash, $428 \mathrm{~kg} / \mathrm{m}^{3}$ cement, $320 \mathrm{l} / \mathrm{m}^{3}$ water, $150 \mathrm{~kg} / \mathrm{m}^{3}$ sand (max. grain size $0.18 \mathrm{~mm}$ ), $150 \mathrm{~kg} / \mathrm{m}^{3}$ quartz powder and chemical admixtures. The tension-softening material was a SFRC consisting of 300 $\mathrm{kg} / \mathrm{m}^{3}$ cement, $792 \mathrm{~kg} / \mathrm{m}^{3}$ sand (0-4 mm), $308 \mathrm{~kg} / \mathrm{m}^{3}$ aggregate (4-8 mm), $703 \mathrm{~kg} / \mathrm{m}^{3}$ aggregate (8-16 mm), $145 \mathrm{l} / \mathrm{m}^{3}$ water, chemical admixtures and $55 \mathrm{~kg} / \mathrm{m}^{3}$ steel fibers (Dramix 3D 45/50) ( $0.7 \%$ by volume). The specimens were demolded 24 to 48 hours after casting and were wet cured at $18 \pm 2^{\circ} \mathrm{C}$. The specimens were covered with wet burlap and plastic sheets during curing for 28 days prior to testing. Table 1 lists the properties of fibers adopted.

Table 1. Properties of fibers

\begin{tabular}{llllllll}
\hline $\begin{array}{l}\text { Material } \\
\text { name }\end{array}$ & Fiber type & $\varnothing, \mu \mathrm{m}$ & $\mathrm{L}, \mathrm{mm}$ & $\mathrm{L} / \varnothing$ & $\mathrm{f}, \mathrm{MPa}$ & $\mathrm{E}, \mathrm{GPa}$ & $\begin{array}{l}\text { Tensile } \\
\text { strain } \\
\text { capacity, \% }\end{array}$ \\
\hline $\begin{array}{l}\text { PVA-ECC } \\
\text { SFRC }\end{array}$ & PVA & 40 & 8 & 200 & 1560 & 40 & 6.5 \\
& $\begin{array}{l}\text { Steel, Hooked- } \\
\text { end }\end{array}$ & 1050 & 50 & 45 & 1115 & 210 & - \\
\hline
\end{tabular}

Compressive strength and secant modulus of elasticity were obtained using standard compression cylinders with a diameter of $100 \mathrm{~mm}$ and height of $200 \mathrm{~mm}$. Six specimens of each material were loaded to failure in compression with a loading rate of $6.28 \mathrm{kN} / \mathrm{s}$. The average compressive strength was 47.5 MPa, and 57.1 MPa for ECC and SFRC, respectively. The average secant elastic modulus in compression was 18.0 GPa in ECC and 34.5 GPa in SFRC. 


\section{Deformation measurements}

A DIC system was used to measure deformations of the front surface of the specimens in the region of interest. Deformations of selected specimens were additionally verified by an arrangement of LVDTs positioned on the back and on the sides of the specimens.

A digital single-lens reflex camera (24 and 36 megapixel) with a $60 \mathrm{~mm}$ macro lens for two dimensional measurements was utilized to provide quantitative and qualitative information on the surface deformations of the specimen. Details of the measurement regions are illustrated in the figures below for each test separately. Digital images were recorded at specific intervals as described below for each test. A commercially available DIC software called Aramis [10] was used to process the images taken during the loading procedure, providing full field deformation measurements of the surface of the specimen, as shown in Figure 1.

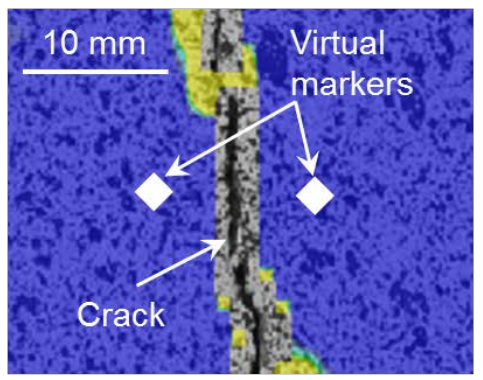

(a)

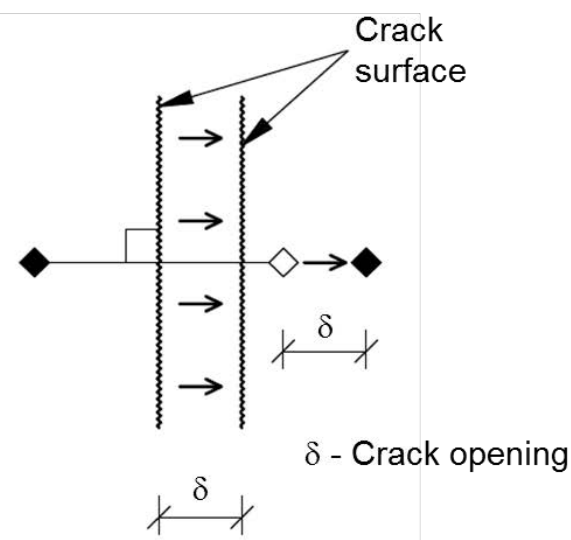

(b)

Figure 1. Illustration of crack deformations: (a) illustration from DIC software; (b) schematic definition of opening

The loading state in each image is correlated by synchronizing the time on the loading machine and that in the image file. In order to achieve adequate contrast in the gray-scale of individual objects, black and white spray paint was used to apply a stochastic spackle pattern on the specimen surface. 
The photogrammetry system tracks movements of small areas (called facets) of the specimen surface corresponding to 15 by 15 pixel square areas; the step of the facets defined in the testing program was 13 pixels. For the most precise measurements, the optimal size of the gray-scale dots should be around $1 / 3$ to $1 / 2$ of a facets size. Additional details on the DIC technique and equipment are available elsewhere [10,11].

\section{Uni-axial Tensile Tests}

Typically for cementitious materials the tensile strength of concrete is given as a percentage of compressive strength; alternatively, the tensile strength can be determined through split cylinder test (e.g., ASTM C496 [12], EN 12390-6 [13]). While the split cylinder test provides sufficient information for brittle cementitious materials, where post-cracking tensile strength is negligible compared to the cracking strength, significant post-cracking strength gain and deformations are evident in ECC and in tension hardening composites, making the split cylinder test unsuitable and therefore requiring new test methods.

\section{$\underline{\text { Single-crack notched coupon test }}$}

The basic tensile material property for FRCC can be measured from a single crack. To isolate a single crack and to avoid multiple cracking, an alternative test method for tension softening as well as strain hardening FRC was developed by Pereira et.al. [2], where the formation of a single, localized crack was consistently verified and a relationship between applied tensile load and crack opening was established.

The tensile stress-crack opening response of ECC was determined using notched coupon specimens with a representative cross section of $8 \mathrm{~mm} \times 30 \mathrm{~mm}$. The size of the notched coupon specimen and the test setup are shown in Figure 2 and Table 2. The notch reduced the tested area of specimen by $60 \%$ to generate a single crack in the specimen even for a strain 
hardening material. Deformation controlled tensile tests $(0.3 \mathrm{~mm} / \mathrm{min}$ loading rate) were conducted using clip-gauges to measure the opening of the predefined single crack at notch. The deformation was applied to the specimen through hydraulic grips providing fixed support at both ends of the specimen [2 and 14]. The specimen geometry used in these investigations was specifically designed for materials with small maximum aggregate size $(0.18 \mathrm{~mm})$ and 'flexible' fibers (i.e., PVA, polypropylene and polyacrylnitrile).

The tensile stress-crack opening response of SFRC was determined using notched cube (150 $\mathrm{mm}$ in size) specimen with a representative notched cross section of $100 \mathrm{~mm} \times 100 \mathrm{~mm}$ (Table 2, Figure 3). The notch reduced the tested area of specimen by $55 \%$ to generate a single tensile crack in the specimen. Cross-head displacement controlled tensile tests were performed with a loading rate of $0.05 \mathrm{~mm} / \mathrm{min}$ up to cross-head displacement of $2 \mathrm{~mm}$ and subsequently the loading speed was raised to $0.5 \mathrm{~mm} / \mathrm{min}$. The crack opening was measured using two clip-gauges across the notch on opposite sides. The test setup and a configuration of the specimen was design to apply the deformations to the specimen near the notch area by rigid steel frame (Figure 3). The size of the specimen is comparable to standard compression cube size and the cross section of standard flexural beams (150mm x 150mm). It is significantly bigger than the size of the specimen utilized for ECC, due to the higher aggregate size and, in general, longer fibers adopted in classical SFRC.

Table 2. Properties of tensile specimens

\begin{tabular}{|c|c|c|c|c|c|c|c|c|c|c|}
\hline Material & Test type & $\begin{array}{l}\text { \# of } \\
\text { specim } \\
\text { ens }\end{array}$ & $\begin{array}{l}\text { Total } \\
\text { length } \\
(\mathrm{H}), \mathrm{mm}\end{array}$ & $\begin{array}{l}\text { Total } \\
\text { width } \\
\text { (B), mm }\end{array}$ & $\begin{array}{l}\text { Total } \\
\text { thickness } \\
(\mathrm{T}), \mathrm{mm}\end{array}$ & $\begin{array}{l}\text { Width } \\
\text { (b), } \\
\text { mm }\end{array}$ & $\begin{array}{l}\text { Thickn } \\
\text { ess (t), } \\
\text { mm }\end{array}$ & $\begin{array}{l}\text { Notch } \\
\text { thickness } \\
\text { (f), mm }\end{array}$ & $\begin{array}{l}\text { Length } \\
\text { (h), } \\
\mathrm{mm}\end{array}$ & $\begin{array}{l}\text { Weight } \\
\text {, kg }\end{array}$ \\
\hline ECC & Single cr. & 10 & $100-120$ & 50 & $12-16$ & 30 & 8 & 0.25 & - & $\leq 0.2$ \\
\hline SFRC & Single cr. & 7 & 150 & 150 & 150 & 100 & 100 & 2.0 & - & 8.2 \\
\hline ECC & DB & 4 & 510 & 75 & 22 & 50 & 22 & - & 200 & 1.3 \\
\hline
\end{tabular}




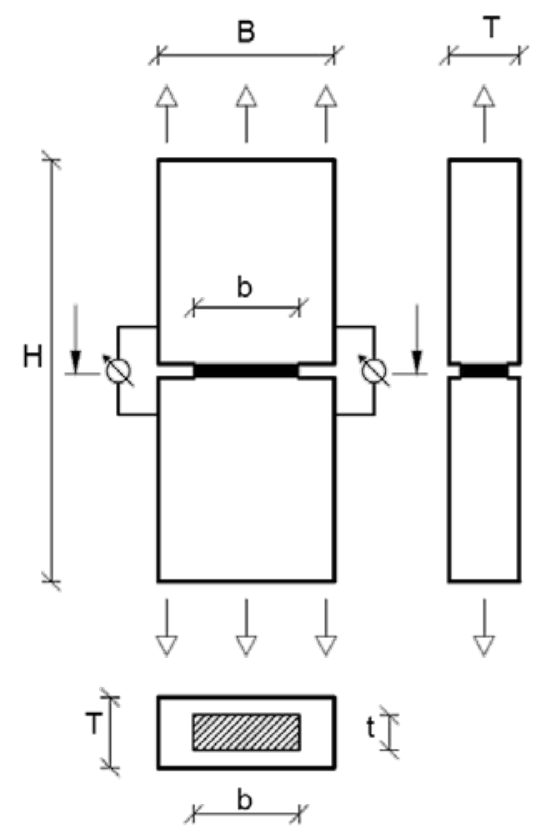

(a)

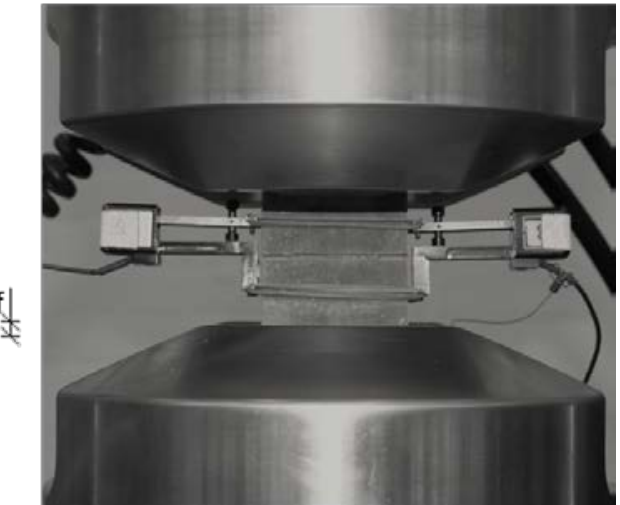

(b)

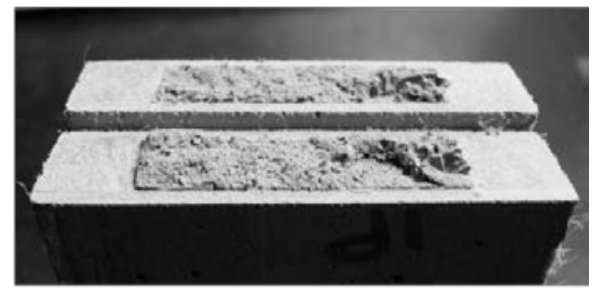

(c)

Figure 2. Single-crack notched coupon test of ECC: (a) specimen geometry; (b) test setup;

(c) specimen after testing

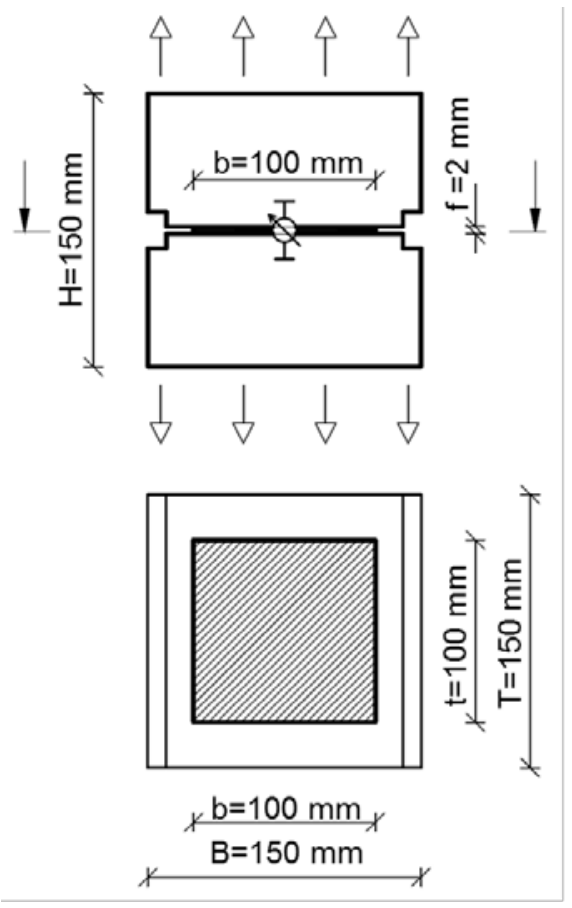

(a)

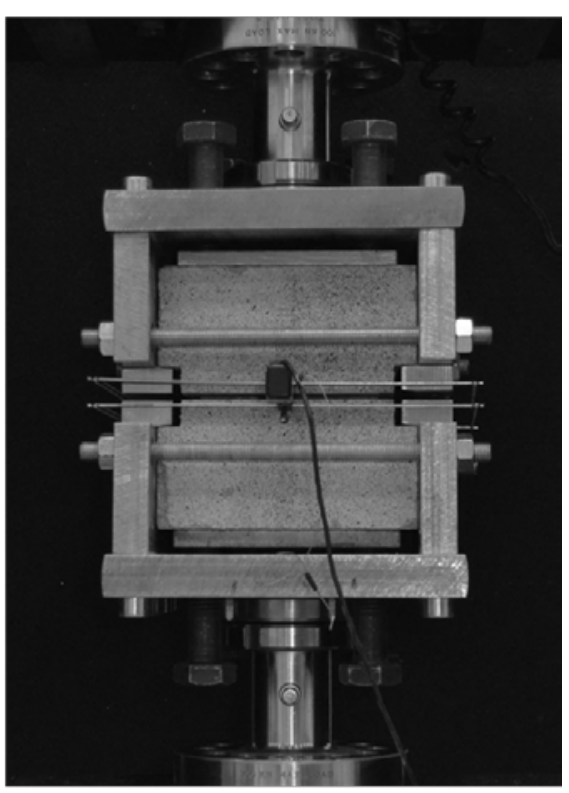

(b)

Figure 3. Single-crack notched coupon test of SFRC: (a) specimen geometry; (b) test setup. 


\section{Dogbone test}

As ECC can have multiple cracking, the single crack behavior does not provide a complete characterization of the material response in uniaxial tension. It is also necessary to determine the strain capacity, crack spacing, and the average, minimum and maximum crack widths at increasing strain levels.

To experimentally determine the tensile stress-strain responses of ECC, dogbone specimens with a representative cross section of $22 \mathrm{~mm}(\mathrm{t}) \times 50 \mathrm{~mm}$ (b) and with a representative length h of $210 \mathrm{~mm}$ were used (Figure 4). Similar to the single crack notched coupon test, the deformation was applied to the specimen through hydraulic grips providing fixed support to both specimen ends. Deformation controlled tensile tests ( $0.5 \mathrm{~mm} / \mathrm{min}$ loading rate) were conducted with linear variable differential transducers (LVDTs) physically measuring the tensile deformations in the specimen. A DIC system was also adopted for measuring crack formations at one second interval.

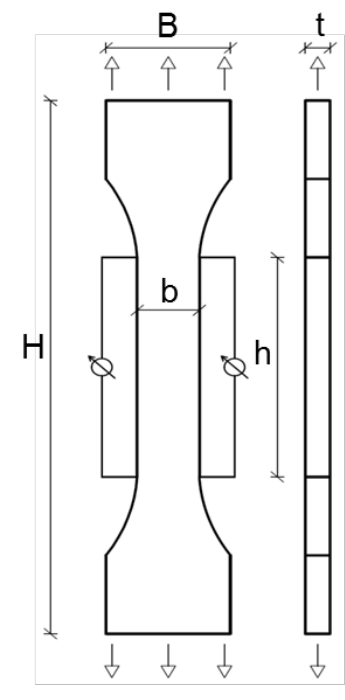

(a)

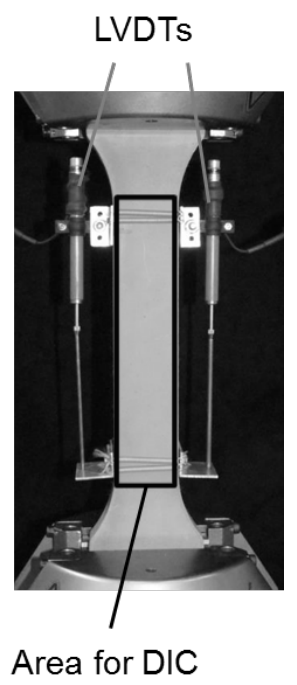

(b)

Figure 4. Tensile dogbone test: (a) specimen geometry; (b) test setup 


\section{Beam tests}

\section{Notched three-point bending beam}

The notched three-point bending test (3PBT) is a standard test method for FRCC described in the fib Model Code [1] (based on EN 14651 [5]) in RILEM Technical Committee guidelines (RILEM TC-162 TDF [15]) as well as in the Japan Concrete Institute (JCI-S-002-2003 [16]). For this study, 3PBTs for both materials were conducted according to EN 14651 [5]. Moreover, for ECC, considering the significantly lower maximum aggregate size, one additional geometry was selected to investigate any possible scale effect. In doing so, the typical geometry for the bending test for mortar [17] was adopted ( 40 x 40 x $160 \mathrm{~mm}$ ). The geometry of the specimens is shown in Figure 5 and the size and the material of the beams are listed in Table 3.

Deformation controlled tests were performed with a loading rate of $0.05 \mathrm{~mm} / \mathrm{min}$ up to a net deflection of $1.2 \mathrm{~mm}$; beyond this point the loading rate was increased to $0.2 \mathrm{~mm} / \mathrm{min}$. The crack mouth opening displacement (CMOD) was measured using a clip gauge and mid-span deflections using LVDTs. The load and deflection measurements were captured with a frequency of $10 \mathrm{~Hz}$. DIC measurements were taken from one surface of the specimen at 4 second intervals.

Table 3. Properties of beam specimens

\begin{tabular}{lllllllllll}
\hline Name & Material & $\begin{array}{l}\text { Test } \\
\text { type }\end{array}$ & $\begin{array}{l}\text { \# of } \\
\text { speci } \\
\text { mens }\end{array}$ & $\begin{array}{l}\text { Span (L), } \\
\text { mm }\end{array}$ & $\begin{array}{l}\text { Dist. to } \\
\text { load point } \\
\text { (a), mm }\end{array}$ & $\begin{array}{l}\text { Height } \\
\text { (h), mm }\end{array}$ & $\begin{array}{l}\text { Width } \\
\text { (b), mm }\end{array}$ & $\begin{array}{l}\text { Notch } \\
\text { depth, } \\
\text { mm }\end{array}$ & $\begin{array}{l}\text { Weig } \\
\text { ht, kg }\end{array}$ & $\begin{array}{l}\text { Slender } \\
\text { ness } \\
\text { (a/h) }\end{array}$ \\
\hline 3P-ECC-40 & ECC & 3PB & 2 & 160 & 60 & 40 & 40 & 8 & 0.5 & $3 / 2$ \\
3P-ECC-150 & ECC & 3PB & 5 & 500 & 250 & 150 & 150 & 25 & 26.2 & $5 / 3$ \\
3P-SFRC-150 & SFRC & 3PB & 3 & 500 & 250 & 150 & 150 & 25 & 32.8 & $5 / 3$ \\
4P-ECC-50 & ECC & 4PB & 3 & 450 & 150 & 50 & 150 & - & 8.7 & 3 \\
4P-ECC-75 & ECC & 4PB & 3 & 450 & 150 & 75 & 150 & - & 10.5 & 2 \\
4P-ECC-150 & ECC & 4PB & 5 & 450 & 150 & 150 & 150 & - & 26.2 & 1 \\
4P-SFRC-150 & SFRC & 4PB & 6 & 450 & 150 & 150 & 150 & - & 32.8 & 1 \\
\hline
\end{tabular}




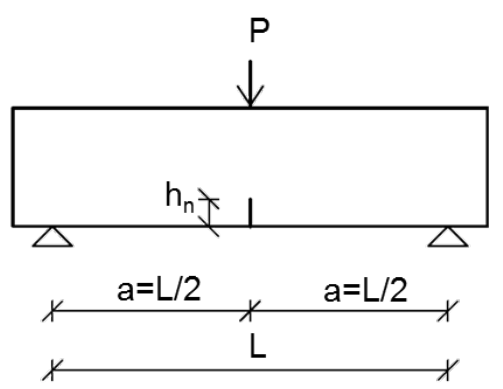

(a)

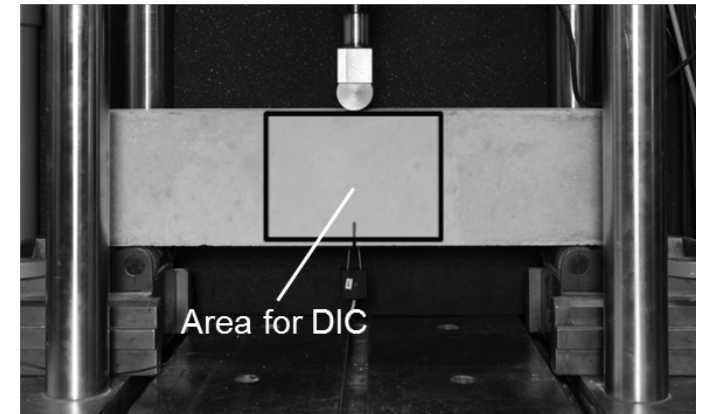

(b)

Figure 5. Notched 3PBT: (a) specimen geometry; (b) test setup with measuring devices.

\section{Four-point bending}

Several standards (ASTM C1609 [6], DAfStb [7], DBV - Guide to Good Practice [18], JCIS-003-2007 [19]) require four-point bending test (4PBT) to characterize FRCC. While ASTM C1609 and JCI-S-003-007 use beams where $b=h=a$ (Figure 6), DAfStb and DBV -

Guide to Good Practice use specimens where $a>b ; h(b=h=150 \mathrm{~mm}$, but a=L/3=200 mm). Some standards allow the use of various sized beams, which should be selected as a function of fiber length (ASTM C1609). Other standards allow using a particular specimen geometry, but set limits to fiber type and properties used in the FRCC (JCI-S-003-2007). In this study, tests according to ASTM C1609 [6] (4P-ECC-150 and 4P-SFRC-150 as in Table 3) of ECC and SFRC were conducted. Additional geometries of ECC beams were investigated with reduced heights of 50 and $75 \mathrm{~mm}$. The specific geometries of the specimens used in this study are reported in Table 3.

The deformation controlled flexural test was performed with a loading rate of $0.05 \mathrm{~mm} / \mathrm{min}$ up to a net mid-span deflection of $0.5 \mathrm{~mm}$, and subsequently the loading speed was slowly raised up to $0.25 \mathrm{~mm} / \mathrm{min}$. The load and LVDT measured deflections were captured with a frequency of $10 \mathrm{~Hz}$, while DIC measurements were taken from one surface of the specimen at four second intervals. 


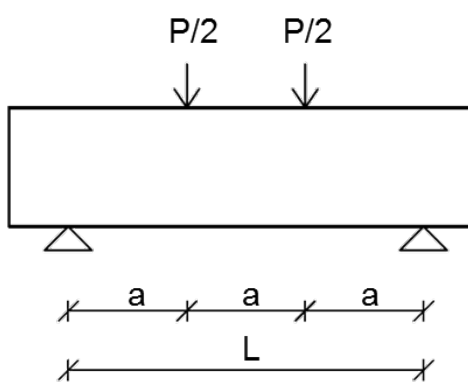

(a)

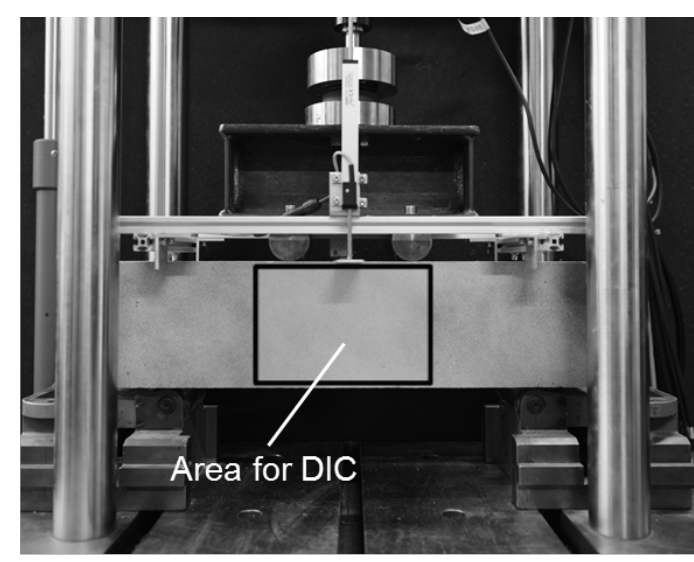

(b)

Figure 6. 4PBT: (a) specimen geometry; (b) test setup with measuring devices.

\section{$\underline{\text { Round determinate panel }}$}

The round determinate panel (RDP) test described in ASTM C1550-10 [8] as a standard test method of FRCC is an externally statically determinate system with a predictable and quantifiable crack pattern (three-line crack pattern can be analytically predicted according to [20,21 and 22]). The experimental program in this study included tests on specimens made according to ASTM C1550-10 as well as smaller panels recently proposed by Minelli and Plizzari [9]. The test-setup of the RDP is shown in Figure 7 and the geometry in Table 4

Table 4. Properties of RDPs

\begin{tabular}{lllllllll}
\hline Name & Material & $\begin{array}{l}\text { Test } \\
\text { type }\end{array}$ & $\begin{array}{l}\text { \# of } \\
\text { specime } \\
\text { ns }\end{array}$ & $\begin{array}{l}\text { Radius } \\
(\mathrm{R}), \mathrm{mm}\end{array}$ & $\begin{array}{l}\text { Radius } \\
\text { of } \\
\text { supports } \\
\text { (r), mm }\end{array}$ & $\begin{array}{l}\text { Height } \\
\text { (h), mm }\end{array}$ & $\begin{array}{l}\text { Weight, } \\
\text { kg }\end{array}$ & $\begin{array}{l}\text { Slendern } \\
\text { ess (r/h) }\end{array}$ \\
\hline P-ECC-60 & PVA-FRCC Panel & 3 & 300 & 275 & 60 & 32.9 & $\sim 4.6$ \\
P-ECC-75 & PVA-FRCC & Panel & 5 & 400 & 375 & 75 & 73.1 & 5 \\
P-SFRC-75 & SFRC & Panel & 6 & 400 & 375 & 75 & 91.6 & 5 \\
\hline
\end{tabular}

The RDP tests were conducted under a deformation controlled procedure with loading rates of $3.0 \pm 1.0 \mathrm{~mm} / \mathrm{min}$. The load and deformation measurements were captured at a frequency of $10 \mathrm{~Hz}$, while DIC measurements were taken from the cracked surface of the panel facing away from the load at ten second intervals. As the DIC measurements utilized are only capturing 2-dimensional deformations, only in-plane crack formation and crack widths were detected and measured by DIC. Specimen deflections at the center point of the panel were 
measured by a LVDT. Moreover, to prevent damage to the camera, specimens were tested upside-down and the camera was positioned above the specimen.

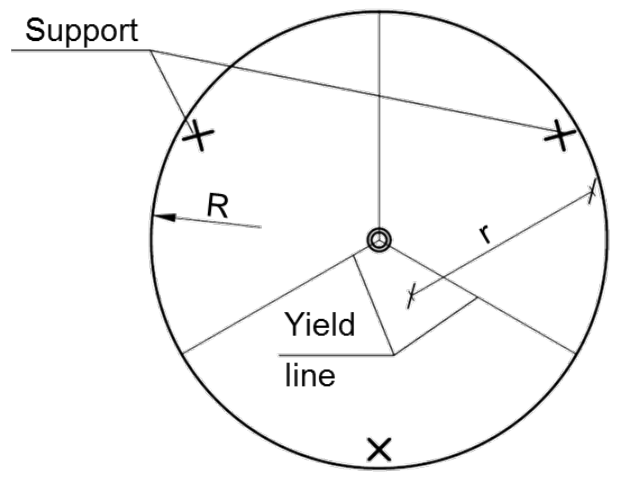

(a)

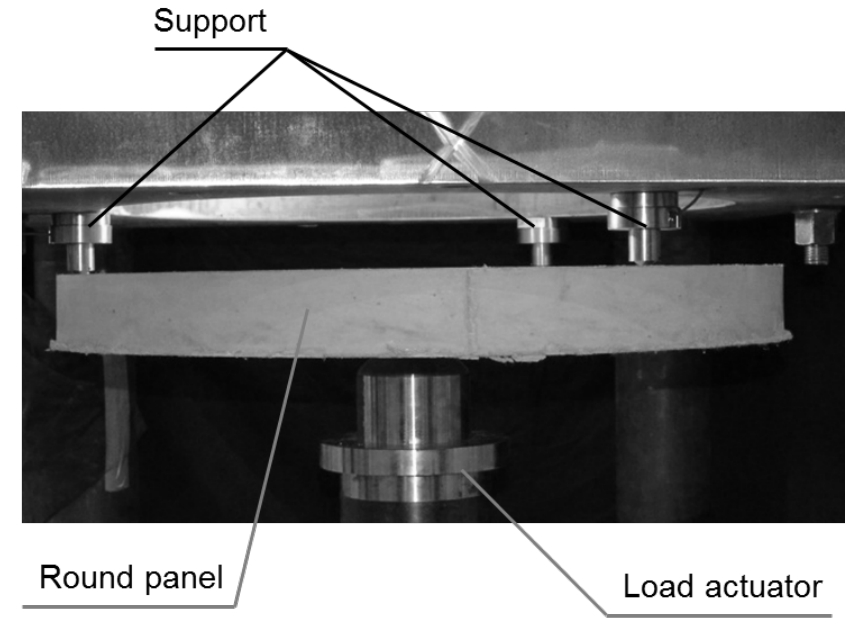

(b)

Figure 7. RDP: (a) specimen geometry (top view); (b) test setup (side view)

\section{RESULTS AND DISCUSSION}

\section{Direct tension}

\section{$\underline{\text { Single-crack notched coupon }}$}

The obtained tensile stress - crack opening relationship for ECC is plotted in Figure 8. The average first cracking strength was $2.9 \mathrm{MPa}$ and ultimate tensile strength was $4.1 \mathrm{MPa}$. The first cracking strength was defined as a local peak or as an abrupt change in stiffness.

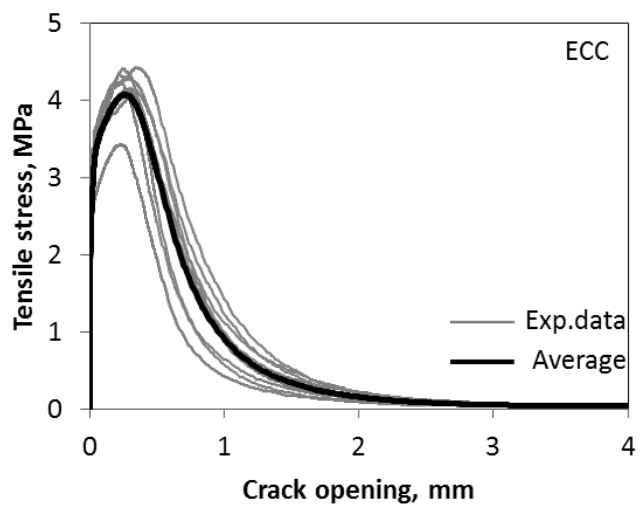

(a)

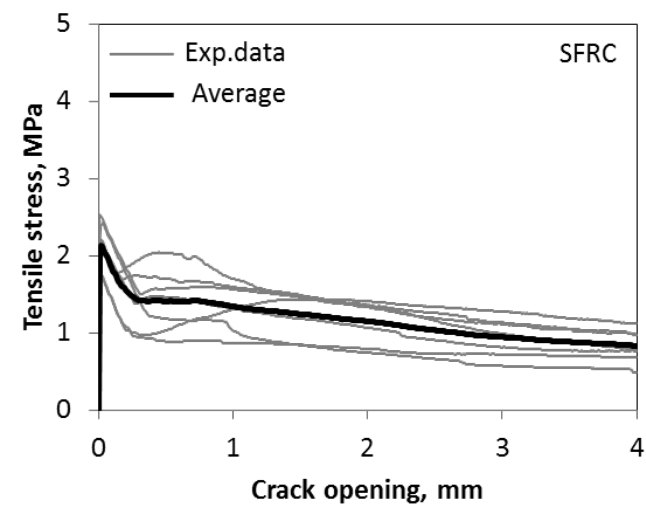

(b)

Figure 8. Tensile stress-crack opening relationships: (a) of ECC and (b) of SFRC 
The first cracking strength of ECC is smaller (2.5 - 3.4 MPa) than the maximum stress that fibers can bridge across the crack (3.4 - 4.4 MPa). As the first cracking strength is lower than the ultimate stress that the fibers can carry over the crack, the multiple cracking and strain hardening behaviors under uni-axial tension in the un-notched ECC material can occur [2, 23]. The ultimate stress that the fibers can carry over the crack can correspond to the smallest value of the sum of pullout strength of all fibers in the cross section or fiber rupture strength, depending on the actual material.

The cracking strength of SFRC was between 1.8 and 2.5 MPa and no distinct second peak in uni-axial tension was observed. Maximum post-cracking strengths varied widely from 0.9 to 2.0 MPa, likely due to the variation in number of fibers bridging the failure plane (23 to 42). The immediate crack opening was approximately $0.2 \mathrm{~mm}$ for all SFRC specimens. For all test types discussed in this paper a fiber pull-out crack failure mechanism was noticed in all SFRC specimens whereas a fiber - rupture of ECC specimens was reported. In the single crack notched specimen the location of the crack is predefined. This does not allow the crack to form in the naturally weakest cross-section. Therefore, this predefined crack might result in a higher measured tensile cracking strength compared to the un-notched sample with constant cross section. However, this influences only the cracking strength but would not affect the measured post-cracking stress transfer.

\section{Dogbone}

Typical tensile stress-strain relationship for ECC is plotted in Figure 9. The average first cracking strength taken from six test specimens was 3.3 MPa and the average ultimate tensile strength was $4.1 \mathrm{MPa}$ at $2 \%-3 \%$ of strain. On the second vertical axis, crack widths measured on one specimen of the series are plotted. During the strain hardening stage additional deformations result in growth of existing cracks and in formation of new cracks. 
At $2.8 \%$ strain level no additional crack formed (stabilized crack stage). This value is quite high compared to classical FRCC. Any further deformation resulted only from widening of existing cracks. Crack localization and subsequent failure occurred when the stress in the specimen reached the maximal bridging strength at the weakest cracked section.

Both tensile test methods provide significant insight for the characterization of ECC. The single crack notched coupon test provides qualitative basic information about the tensile stress - crack opening response. Moreover, it also indicates whether the material is strain hardening or softening in tension - if the first cracking strength is lower than the peak bridging strength, the material should have strain hardening behavior in uni-axial tension. The dogbone test characterizes the overall strain capacity, crack distribution and ductility. For tension softening cementitious composites, the single crack coupon and dogbone tests will show similar information as failure in tension softening materials by definition occurs at a single crack location.

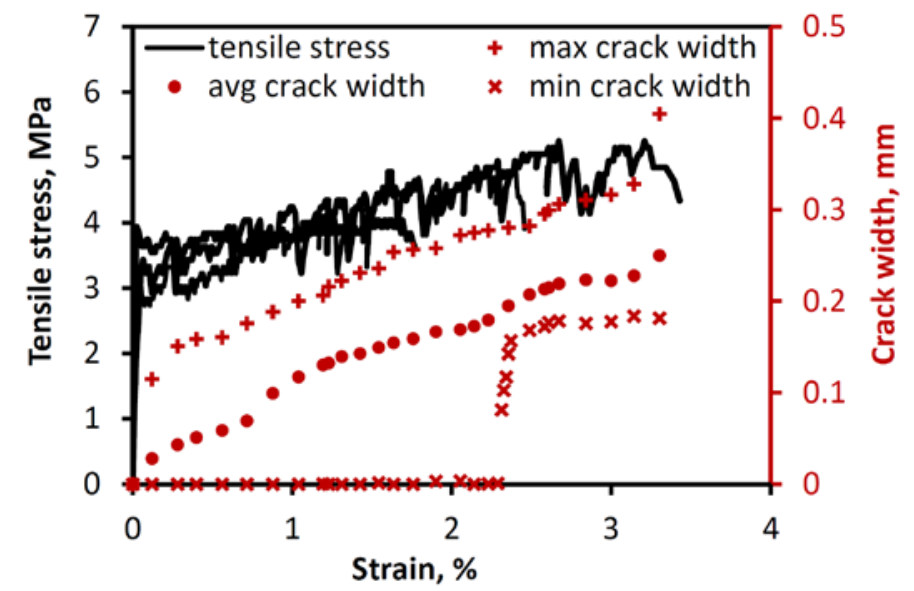

Figure 9. Tensile properties of ECC

\section{Flexural beam}

Notched three-point bending test.

Figure $10(\mathrm{a}-\mathrm{c})$ presents load versus CMOD curves of SFRC and ECC beams with various dimensions. The secondary vertical axis of these diagrams provides the residual flexural 
stress calculated as material would be in elastic stage (called also as equivalent elastic

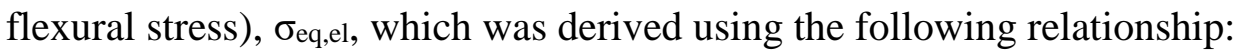

$\sigma_{e q, e l}=\frac{3 P L}{2 b\left(h-h_{n}\right)^{2}}$

where:

P - applied load;

L -beam span;

b - beam width;

h - beam height;

$h_{n}-$ notch depth.

Moreover, average residual flexural tensile strength values $\left(f_{R, j}(j=1 \ldots 4)\right)$, determined according to EN 14651 [5] at CMOD of $0.5 \mathrm{~mm}, 1.5 \mathrm{~mm}, 2.5 \mathrm{~mm}$ and $3.5 \mathrm{~mm}$ respectively, and the residual flexural tensile strength at peak load $\left(f_{\text {peak }}\right)$ are shown for all tested samples in Figure 10(a-c).

The residual tensile stresses are defined as follows:

$$
f_{R, j}=\frac{3 P_{j} l}{2 b h_{s p}^{2}}
$$

where:

$f_{R, j}$ is the is the residual flexural tensile strength corresponding to CMOD=CMODj; $P_{j}$ - load corresponding to $\mathrm{CMOD}_{\mathrm{j}}$ (see Figure 10);

$h_{s p}$ - distance between the notch tip and the top of the specimen $\left(h_{s p}=h-h_{n}=125 \mathrm{~mm}\right)$.

Figure 10 (a) and (b) illustrates results for ECC beams $40 \mathrm{~mm}$ and $150 \mathrm{~mm}$ high, respectively. Independent of the specimen dimension, the ECC material is found to have a deflection hardening response, with average peak loads approximately 2 times larger than first cracking load. Comparing the results obtained from the standard beam size and the smallest beam size, 
the maximum residual strength measured in the smallest specimen (3P-ECC-40) is $12.2 \mathrm{MPa}$, or 1.5 times greater than the standard sized beam (3P-ECC-150, 8.0 MPa).

Figure 10 (c) shows two of the three tested SFRC beams, which experienced a light deflection softening behavior with a first cracking load slightly higher ( 6\%) than the second peak due to fiber bridging action. The remaining samples, on the contrary, showed a deflection hardening response with the second peak approximately $8 \%$ higher than the first peak. On average, this test method indicates that the SFRC material investigated had approximately a constant (approaching plastic) response, which was neither strictly hardening nor strictly softening in the observed range of CMOD.

Figure 10 (d) reports the average residual flexural stresses versus CMOD normalized by the CMOD at peak load for ECC specimens 150 and $40 \mathrm{~mm}$ high. The shapes of the curves for both ECC beams are similar including the descending branch; however, the smallest specimen (3P-ECC-40) transferred higher equivalent elastic stress at all CMOD values. The higher stresses in smaller beams can be attributed to size effect in tension, to an increased impact of the wall effect, causing preferential orientation of fibers in the smaller specimens, and, last but not least, to the higher strain gradient experienced by shallower elements for the same top or bottom strain, which leads to a higher sectional redistribution of stresses.

Figure 11 (a) and (b) show typical crack patterns for the ECC beams at peak load from DIC measurements. The images indicate that multiple cracking occurs in ECC before the peak load, regardless of beam dimension and of the cross-sectional reduction at the notch (i.e., point of maximum moment). Cracking can be observed on both sides of the notch, indicating that additional deformation occurs beyond notch opening. Therefore, as multiple cracks form, not all deformations are captured by a CMOD gauge located at the notch as specified in the standard. 
Peak load in the SFRC beams typically resulted in a single crack at the notch location (Figure 11 (c)). Additional cracks, as shown in Figure 11 (d) are reported at CMOD=1 mm. Although, Figure 8 (c) indicates that the investigated SFRC was not clearly a deflection hardening material, a multiple cracking response was observed at peak load in Figure 11 (d). Therefore, for both materials herein considered (ECC and SFRC), a notched 3PBT, where only load and CMOD are measured, does not provide a comprehensive representation of the material properties.

Generally speaking, in the case of typical SFRC, the notch could be detrimental in case of materials exhibiting a plastic or strain-hardening behavior. On the contrary, in typical strainsoftening SFRC, this unwanted multiple-cracking phenomenon at the notch would not be established, leading to a more consistent and reliable testing procedure.

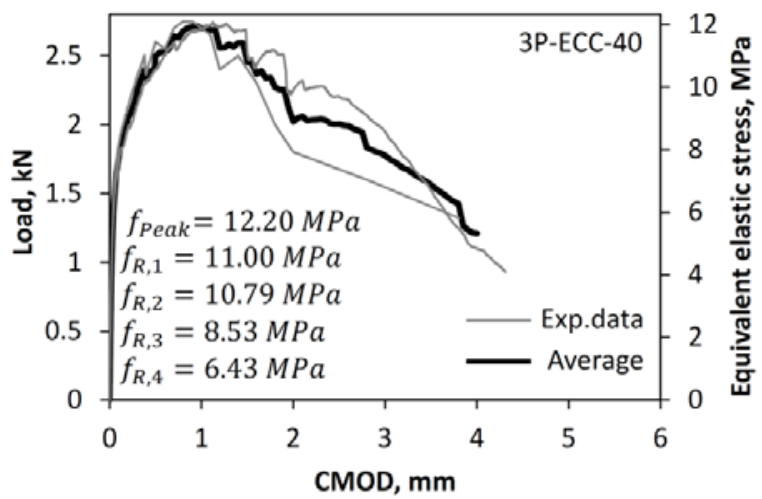

(a)

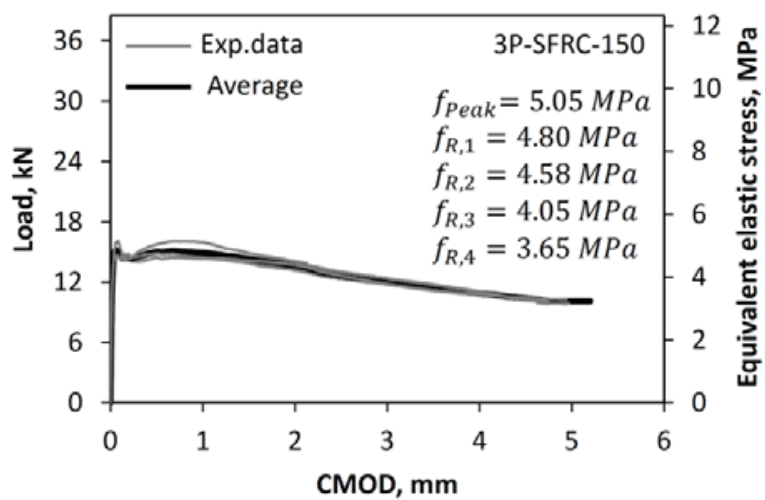

(c)

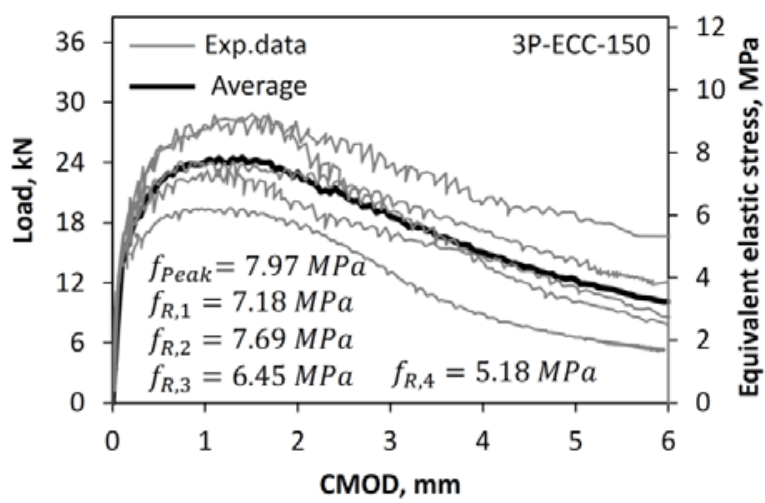

(b)

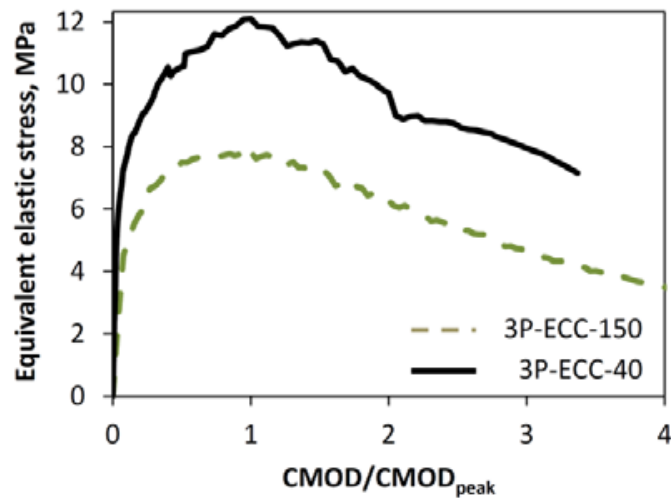

(d)

Figure 10. Load - CMOD relationships of three-point bending beams: (a) 3P-ECC-4150; (b) 3P-ECC-40; and (c) 3P-SFRC-150; (d) comparison between 3P-ECC-40 and 3P-ECC-150 


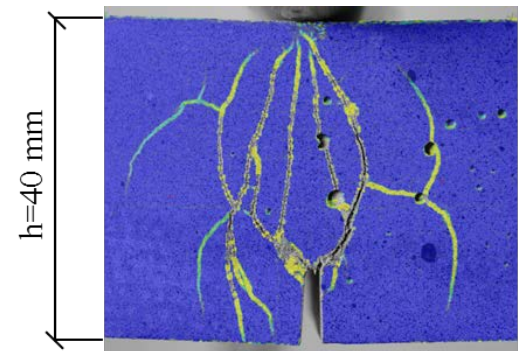

(a)

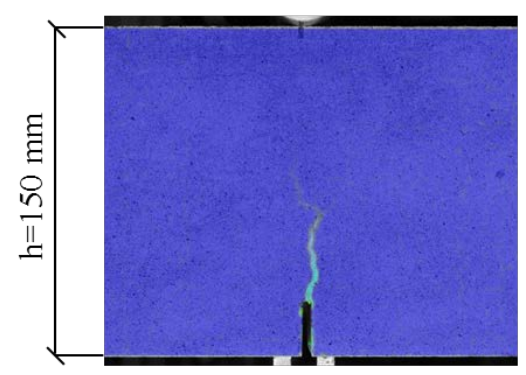

(c)

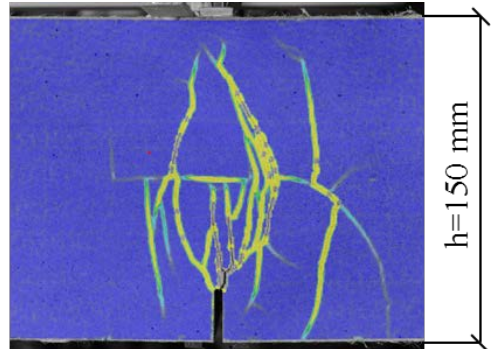

(b)

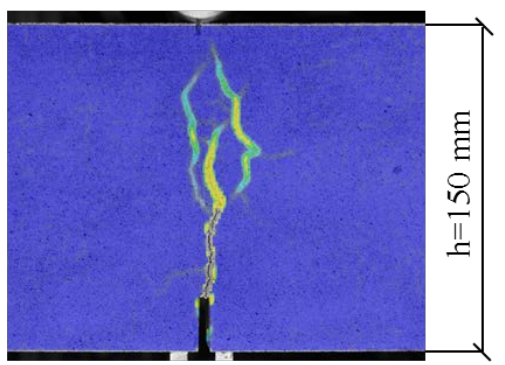

(d)

Figure 11. Crack distribution of FRCC beams under three-point bending: a) 3P-ECC-40 at peak, b) 3P-ECC-150 at peak, c) 3P-SFRC-150 at peak and d) 3P-SFRC-150 at CMOD of 1 $\mathrm{mm}$

As a general observation, in a 3PBT configuration, both strain and stress fields are much more complicated than those assumed in corresponding standards. The point load and the notch at the same cross section provides stress concentration and the weakened cross section is disturbed with a stress field far from being in accordance with the beam theory. High shear stresses, vertical normal stresses $\left(\sigma_{\mathrm{y}}\right)$ related to the vertical load and a relatively strong disturbance due to the notch (both at the mid-span) develop. As a result, the material characteristics obtained by notched 3PBTs are not fully representative, especially when more than one single crack develops. This fact entirely excludes strain hardening materials from being evaluated by the notched 3PBT. Furthermore, this study presents indications that nominally tension softening materials, such as SFRC, are also experiencing unexpected disturbances due to the presence of the notch. In conclusion, the notched 3PBT does not characterize the flexural response of the material as is suggested in the standard since the 
notched mid-span section behaves as a so-called “disturbed region” (D-region), far from being subjected to a flexure-dominant stress field according to Bernoulli beam theory ("Bregion”) [24].

\section{Four-point bending}

Figure 12 shows load-deflection curves of 4PBTs for ECC beams of varying dimension and SFRC. The secondary vertical axis provides the residual flexural stress $\left(\sigma_{\text {eq,el }}\right)$, calculated by: $\sigma_{e q, e l}=\frac{P L}{b h^{2}}$

Where:

P - applied load;

L - beam span;

b - beam width;

h - beam height;

The plotted values shown in the diagram $f_{\text {Peak, }} f_{600}^{D}$ and $f_{150}^{D}$ are average residual strength values determined according to ASTM C1609 [6] at peak load, net deflection of L/600 (0.75 $\mathrm{mm})$ and L/150 (3 $\mathrm{mm})$ respectively.

Figure 12 (a, b and c) presents the results of ECC beams with 50, 75 and $150 \mathrm{~mm}$ beam height, respectively. While all ECC beams had similar average peak strength (between 8.60 MPa and 9.35 MPa), beams with reduced height (4P-ECC-50/150 and 4P-ECC-75/150) had higher deflections at similar equivalent elastic flexural stress. The increased slenderness of shallowest members determined a decrease in the stiffness and, in addition, a significant enhancement of the ductility.

Figure 12 (c) and (d) show results of ECC and SFRC beams respectively, with geometries according to ASTM C1609. Peak strength of ECC (8.50 MPa) is almost twice as high as that of SFRC (4.45 MPa), whereas the residual strength at a mid-span deflection of L/150 (or 3 
$\mathrm{mm}$ ) is similar for both materials (2.70 MPa for ECC and 2.95 MPa for SFRC). This indicates that even though ECC can resist a higher maximum load, the post-peak behavior of SFRC is more stable (i.e., with increasing deflection, the decay in flexural strength is more gradual in SFRC). This is certainly due to the differences in the interfacial properties between fibers and cementitious matrix, to the different aggregate size and to the fiber properties. In fact, short fibers (8 mm PVA fibers) are able to resist and activate the bridging action for small values of crack opening. On the contrary, $50 \mathrm{~mm}$ long steel fibers start working at higher level of crack widths but are able to effectively bridge cracks for rather high values of crack width (up to $3 \mathrm{~mm}$ ). From a material design point of view, this suggests that the utilization of PVA fibers would provide high performance under service conditions (SLS), whereas a structure would more benefit from long steel fibers at the ultimate limit states (ULS). This also leads to a potential combined utilization of the two types of fibers, by suitably design a proper mix composition that could enhance this hybrid fiber system. Figure 13 (a) and (b) show typical peak load crack patterns in ECC beams 50 and 75 mm high. Beam 4P-ECC-50 in Figure 11(a) has a classical (i.e., Bernoulli) flexural behavior with well distributed flexural cracks with a regular crack spacing of approximately $13 \mathrm{~mm}$ over the constant moment region. The same evidence was found for sample 4P-ECC-75 (Figure 11(b)), showing an average crack spacing of approximately $20 \mathrm{~mm}$. In contrast, for the ECC beam 150 mm high (4P-ECC-150), cracking was irregular with many cracks located in the linear moment region, characterized by a typical mixed shear-flexure crack pattern. This fact is certainly due to the different slenderness of samples.

Figure 13 (d) shows a typical SFRC beam with a single main crack in the constant moment region at peak load. Smaller secondary cracks were observed, however, before the peak load, in the majority of the tested SFRC beams, even outside the middle third of beam, with a maximum crack width of $0.03 \mathrm{~mm}$. 


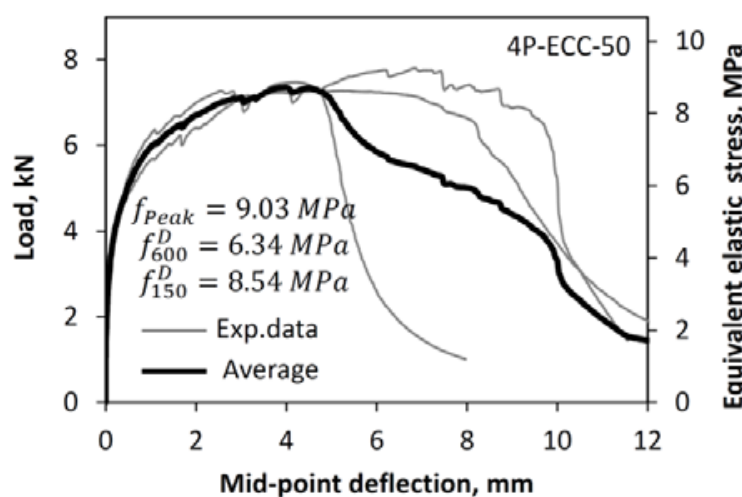

(a)

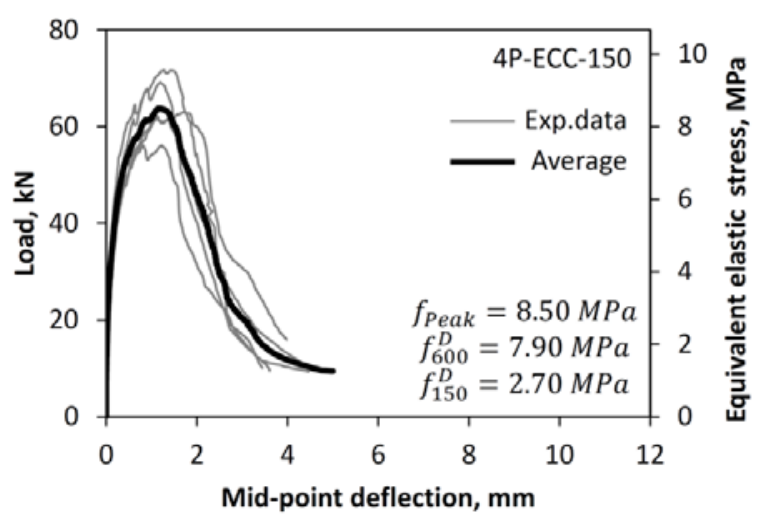

(c)

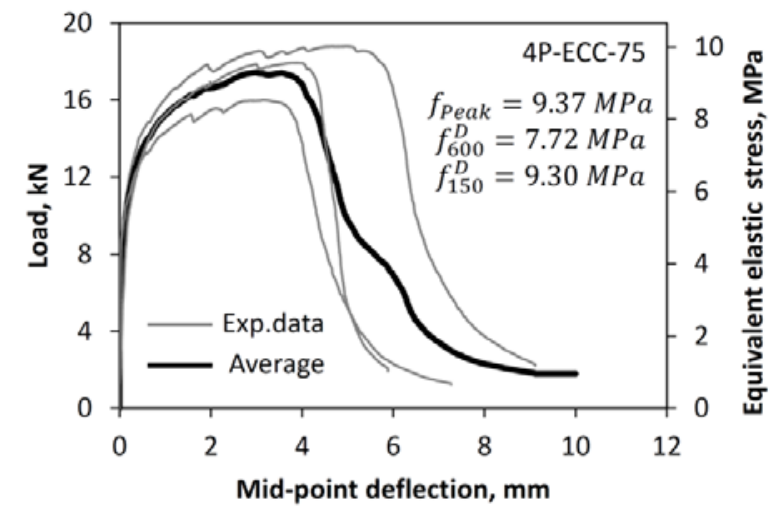

(b)

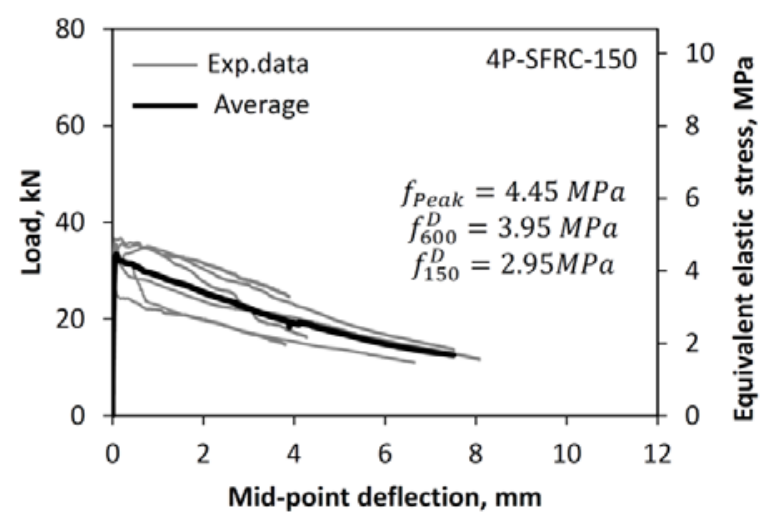

(d)

Figure 12. Load - mid-span deflection relationships of four-point bending beams

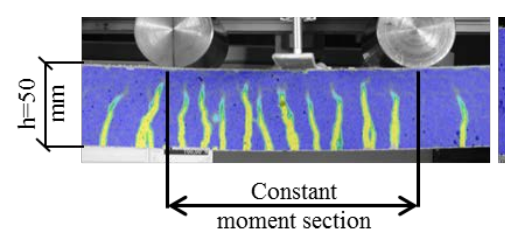

(a)

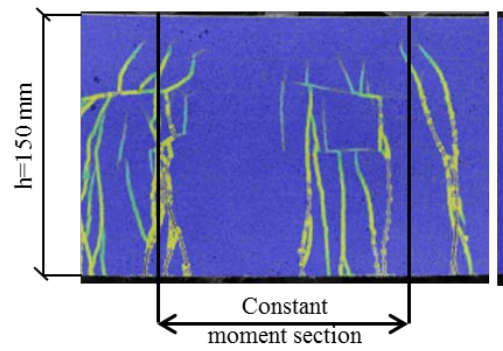

(c)

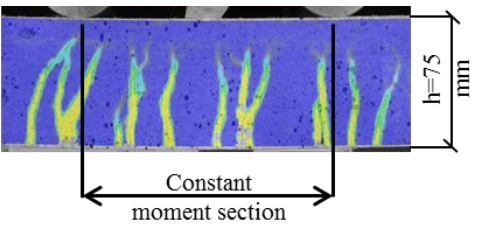

(b)

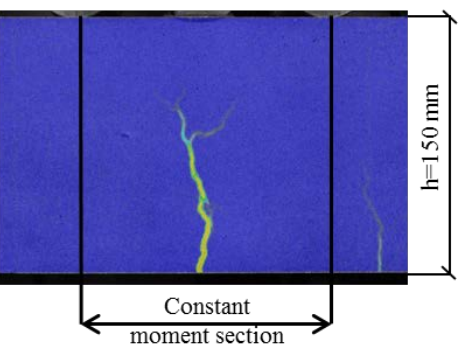

(d)

Figure 13. Typical crack patterns at peak load: (a) 4P-ECC-50; (b) 4P-ECC -75; (c) 4P-ECC

-150 and (d) SFRC beam 
Although, the constant moment region of the four-point bending beam theoretically allows for the formation of multiple cracking of deflection hardening materials, cracks often occurred outside of this region for the ECC beams. In this case, cracks are influenced also by shear. The influence on shear stresses on flexural performance was significant for the beams having a depth equal to $1 / 3$ of the span (4P-ECC-150), as several cracks appeared outside the flexural span. Moreover, cracks were more concentrated in the region under the two loading points and were inclined (see Figure 13 (c)) with a typical mixed shear-flexure crack pattern. In contrast, the ECC beams with reduced thickness (i.e. more slender) were found to have a regular multiple crack pattern in the constant moment region with minor additional cracks forming outside the constant moment region.

In case of failure occurring outside the constant moment region, the corresponding test results cannot be used according to the procedure described in ASTM C 1609. Based on the general experience at the Technical University of Denmark, failure cracks form outside the constant moment region in more than 25\% of the ASTM beam made by ECC. To reduce the influence of shear stresses, a slenderer beam geometry (i.e., reduced beam height, increased span length, or both) is recommended. As ECC is typically envisaged to be used in relatively slender structures with thicknesses of 50-75 mm, the ASTM beam test with reduced thickness would be preferable.

\section{Round determinate panel}

Figure $14(\mathrm{a}, \mathrm{b})$ presents the load-center point deflection responses for ECC classical round determinant panels (RDP) according to ASTM C1550 [8] and according to the smaller geometry suggested in [9]. To determine peak strength of the RDP, the corresponding moment for the centrally applied peak load should be determined. The flexural peak strength, $f_{\text {Peak }}$, using elastic theory can be determined as follows: 
$f_{\text {Peak }}=\frac{2 r P_{p}}{\sqrt{3} R h^{2}}$

where:

$P_{p}$ - peak load;

$\mathrm{r}$ - radius of supports;

$\mathrm{R}$ - radius of panel;

$\mathrm{h}$ - panel height;

Regardless of the dimensions of the panel (standard or modified), similar deflection hardening responses of ECC were observed with the conventional ASTM C1550 RDP providing slightly higher peak strength and corresponding deflection compared to the smaller RDP. The calculated average peak strength of ECC panels was 8.5 and 8.1 MPa for the conventional and modified panel geometry, respectively.

Figure 14(c) presents the load-center point deflection responses of SFRC ASTM C1550 [8] panels, showing a deflection softening response similar to that of 4PBTs with SFRC (Figure 12). The peak strength of the SFRC panel was $5.4 \mathrm{MPa}$, which is 1.5 times lower than the peak strength of the corresponding ECC panel. However, as already previously noticed in the other test typologies, in SFRC panels more gradual decay in strength than in ECC for increasing deformation can be clearly observed.

Figure 14 (d) presents the specific work versus normalized deflection (with respect to the panel radius) for all RDPs. The Specific work was calculated using the following relationship:

$\bar{W}=\frac{1}{3 R h} \int_{0}^{\Delta} P d \Delta$

Where:

$\bar{W}$ - specific work;

$\Delta$ - center-point deflection; 
P - point load;

$\mathrm{R}$ - panel radius;

$\mathrm{h}$ - panel height.

From Figure 12 (d) it emerges that the panel size does not significantly influence the basic behavior of ECC as the shape of specific work versus normalized deflection curves is very similar. As the studied ECC was able to carry higher loads than the SFRC used in this study, the energy absorbed is higher for ECC to reach the same deflections. ASTM C1550 requires determination of energy absorption at the center point deflection values of 5, 10, 20 and 40 $\mathrm{mm}$.

Testing of the ECC panels was stopped when the post-peak load was $<4 \mathrm{kN}$, at a center-point deflections in the range of 22 to $32 \mathrm{~mm}$. The maximum obtained energy for the standard ECC RDP (P-ECC-75) was $737 \mathrm{~J}$ (specific work, $\bar{W}=8.2 \mathrm{~kJ} / \mathrm{m}^{2}$ ). The SFRC panels collapsed at a deflection well beyond $40 \mathrm{~mm}$, with an average energy absorbed (at $40 \mathrm{~mm}$ deflection) of $585 \mathrm{~J}$ (specific work, $\bar{W}=6.5 \mathrm{~kJ} / \mathrm{m}^{2}$ ).

This further confirms that ECC works better for small and well distributed cracks. Therefore, the $40 \mathrm{~mm}$ request of ASTM C1550 [8] is in contrast with the nature of the material, which provides much more energy absorption for low levels of displacement.

DIC measurements of ECC specimens tested according to ASTM C 1550 [8] are presented in Figure 15(a, b and c). The occurrence of first crack in the specimen is difficult to capture as multiple cracks form at nearly the same time (Figure 15 (a)). The initial cracks are approximately along the three yield lines starting from the load-point and developing towards the direction of the mid-span between neighboring point-supports (Figure 7 and Figure 15 a). Additional deflection causes new cracks to form and the existing cracks to widen (Figure 15 b). At the peak load (Figure 15(c)) almost all cracks have formed and a circular fan-shaped yield pattern can be observed. In the post peak deformation regime typically three localized 
cracks develop from the load-point towards the direction of the mid-span between neighboring point-supports.

The DIC results in the case of SFRC panels are presented in Figure 15(d - e). Similar to ECC, the first crack in the specimen was not possible to univocally capture as a number of small cracks formed at nearly the same time (Figure 15(d)). Once the peak load was reached, three main cracks can be observed in the direction of the predicted yield lines; however, multiple smaller cracks are present as well (Figure 15(e)). After the peak load, no new cracks form and the existing significantly widen.

The formation of multiple cracking in SFRC panels investigated in this study differs from the experimental results on strictly tension softening materials obtained by Minelli and Plizzari [9], who tested panels of SFRC containing $25-30 \mathrm{~kg} / \mathrm{m}^{3}$ of macro steel fibers $\left(\mathrm{V}_{\mathrm{f}}=0.32-\right.$ 0.38\%), which is approximately half the fiber volume fraction described in this paper. The increased steel fiber volume fraction may explain the differing material response as fewer fibers bridging a crack results in a reduced load transfer across a crack and, consequently, the possibility that multiple cracking can occur is strongly reduced.

Furthermore, the multiple cracking, in sufficiently tough SFRC, was already noticed in both beam test typologies previously reported. 


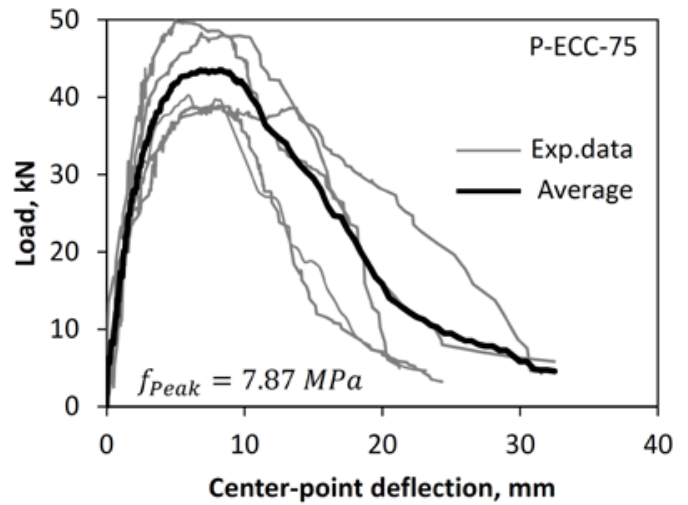

(a)

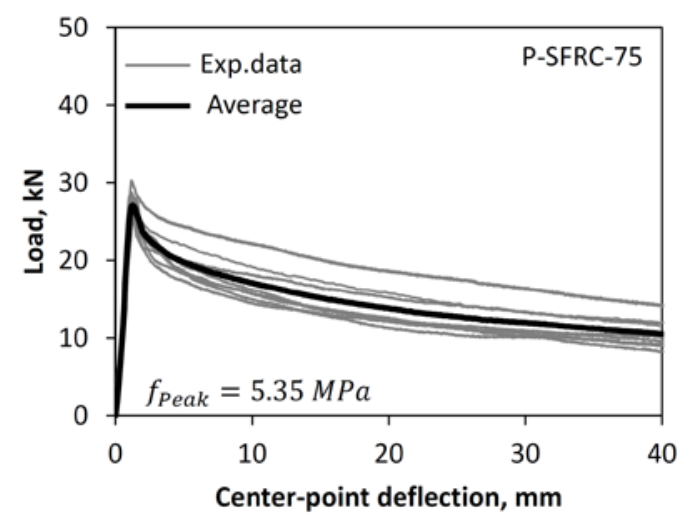

(c)

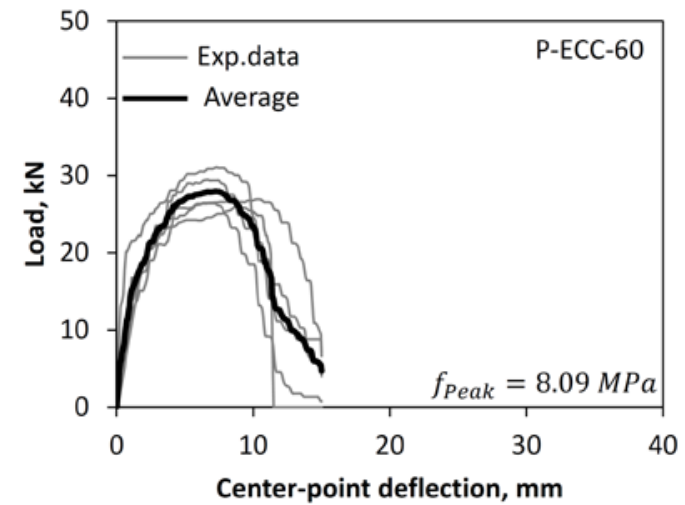

(b)

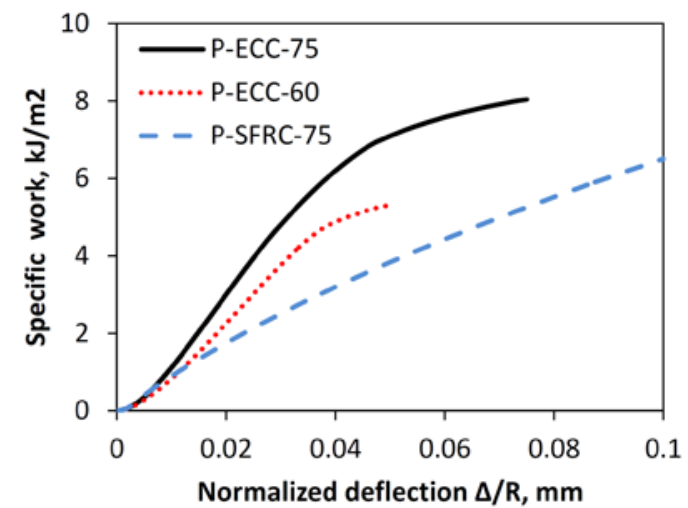

(d)

Figure 14. Load - deflection curves of RDPs.

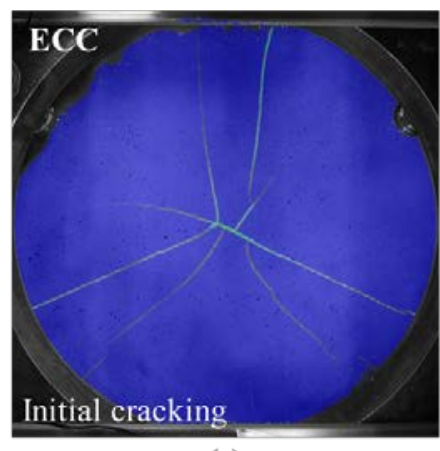

(a)

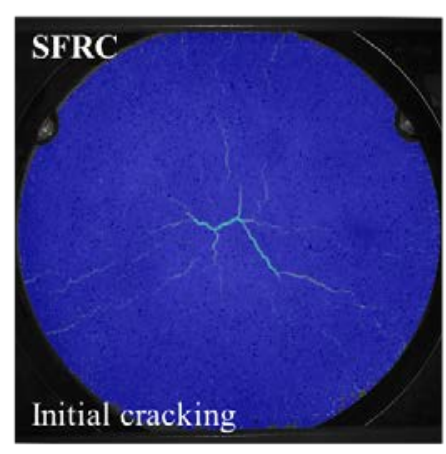

(d)

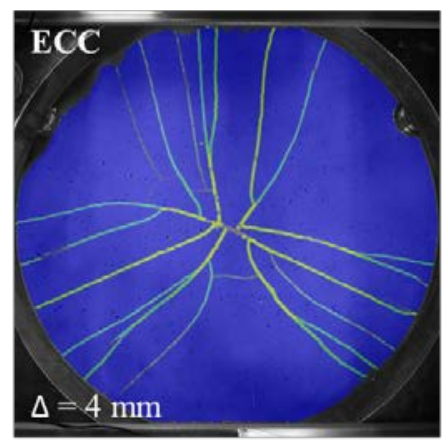

(b)

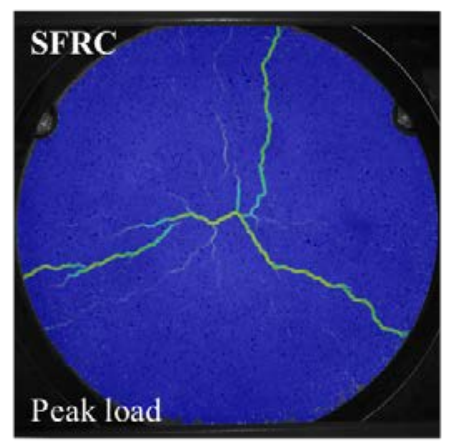

(e)

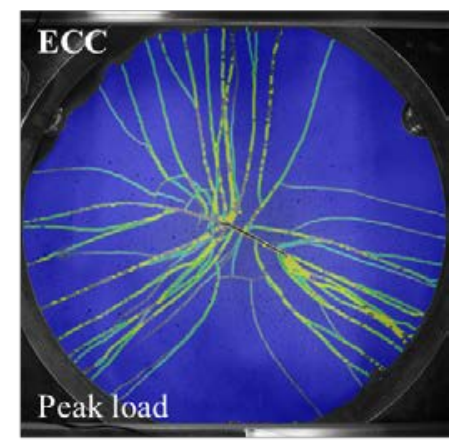

(c)

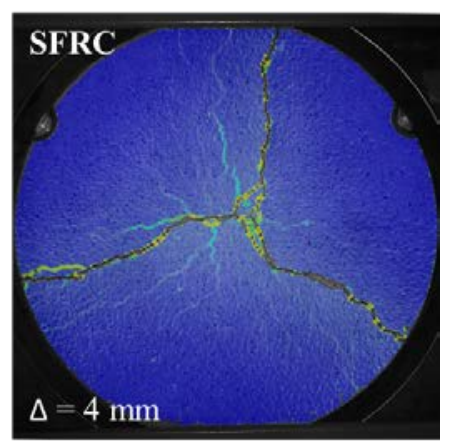

(f)

Figure 15. Crack patterns of typical round panels specimen: P-ECC-75 (a) (b) (c); P-SFRC75 (d) (e) (f). 
A RDP test, such as ASTM C 1550, provides an alternative test method that accounts for both the material property of multiple cracking (if the material has a hardening characteristic) and the structural property of forming multiple (three) yield lines. In some cases, results obtained by the RDP test have lower variability due to its increased fracture area compared to beam tests [9]. However, results of the RDP test are difficult to interpret and more refined analytical techniques have to be adopted to implement them in structural design [25].

\section{Variability of test results within each test series}

Coefficients of variation, which describe the variability of test results, are presented in Table

5 for all test results. In the case of ECC, for all test methods the coefficient of variation is relatively constant. The SFRC test results did not show a higher variability compared to ECC, except in the 4PBTs. 3PBTs of SFRC evidenced very repeatable results with rather low scatter, in contrast to what was found by Minelli and Plizzari [9]. The different observations can be explained by the fact that in the previous study, strain softening materials with a relatively low content of fibers were studied $\left(\mathrm{V}_{\mathrm{f}}=0.3 \%\right)$, whereas the SFRC material in this study has $\mathrm{V}_{\mathrm{f}}=0.7 \%$. The increased fiber content yielded a more uniform fiber distribution in both RDP and beam specimens.

Therefore, no considerable reductions in variability were observed for results of RDPs compared to the beam tests for the materials investigated here. As a result, the RDP test, which was suggested to be effective for strain softening materials to significantly reduce the variability [9], is found to be not very convenient for the materials herein considered, as it is harder to perform using standard laboratory facilities and the results are less straight forward to interpret. 
Table 5. Overview of statistical evaluation of test results

\begin{tabular}{|c|c|c|c|c|c|c|}
\hline \multicolumn{7}{|c|}{ Coefficient of variation (standard deviation/average value) } \\
\hline \multicolumn{7}{|c|}{ Three-point bending } \\
\hline & Peak load & $\begin{array}{l}\text { Deflection at } \\
\text { peak load }\end{array}$ & $\begin{array}{l}\text { Load at } \\
\text { CMOD=0.5 } \\
\text { mm }\end{array}$ & $\begin{array}{l}\text { Load at } \\
\mathrm{CMOD}=1.5 \\
\mathrm{~mm}\end{array}$ & $\begin{array}{l}\text { Load at } \\
\text { CMOD=2.5 } \\
\mathrm{mm}\end{array}$ & $\begin{array}{l}\text { Load at } \\
\mathrm{CMOD}=3.5 \\
\mathrm{~mm}\end{array}$ \\
\hline 3P-ECC-40 & 0.02 & 0.15 & 0.06 & 0.03 & 0.20 & 0.06 \\
\hline 3P-ECC-150 & 0.16 & 0.24 & 0.14 & 0.16 & 0.20 & 0.29 \\
\hline 3P-SFRC-150 & 0.05 & 0.02 & 0.04 & 0.03 & 0.02 & 0.03 \\
\hline \multicolumn{7}{|c|}{ Four-point bending } \\
\hline & Peak load & $\begin{array}{l}\text { Deflection at } \\
\text { peak load }\end{array}$ & $\begin{array}{l}\text { Load at } \\
\Delta=\mathrm{L} / 600 \\
(0.75 \mathrm{~mm})\end{array}$ & $\begin{array}{l}\text { Load at } \\
\Delta=\mathrm{L} / 300 \\
(1.5 \mathrm{~mm})\end{array}$ & $\begin{array}{l}\text { Load at } \\
\Delta=\mathrm{L} / 150 \\
(3.0 \mathrm{~mm})\end{array}$ & $\begin{array}{l}\text { Load at } \\
\Delta=\mathrm{L} / 100 \\
(4.5 \mathrm{~mm})\end{array}$ \\
\hline 4P-ECC-50 & 0.04 & 0.24 & 0.05 & 0.05 & 0.01 & 0.01 \\
\hline 4P-ECC-75 & 0.08 & 0.23 & 0.05 & 0.06 & 0.08 & $0.38^{*}$ \\
\hline 4P-ECC-150 & 0.10 & 0.18 & 0.07 & 0.10 & $0.33^{*}$ & 0.10 \\
\hline 4P-SFRC-150 & 0.04 & 0.28 & 0.20 & 0.20 & 0.21 & 0.19 \\
\hline \multicolumn{7}{|c|}{ Round determinate panel } \\
\hline & Peak load & $\begin{array}{l}\text { Deflection at } \\
\text { peak load }\end{array}$ & $\begin{array}{l}\text { Energy } \\
\text { absorbed at } \\
\Delta=\mathrm{R} / 80\end{array}$ & $\begin{array}{l}\text { Energy } \\
\text { absorbed at } \\
\Delta=\mathrm{R} / 40\end{array}$ & $\begin{array}{l}\text { Energy } \\
\text { absorbed at } \\
\Delta=\mathrm{R} / 20\end{array}$ & $\begin{array}{l}\text { Energy } \\
\text { absorbed at } \\
\Delta=\mathrm{R} / 10\end{array}$ \\
\hline P-ECC-60 & 0.06 & 0.20 & 0.17 & 0.11 & 0.16 & - \\
\hline P-ECC-75 & 0.12 & 0.28 & 0.18 & 0.15 & 0.19 & - \\
\hline P-SFRC-75 & 0.05 & 0.11 & 0.08 & 0.09 & 0.11 & 0.14 \\
\hline
\end{tabular}

*- after one of the specimens has failed

\section{Comparison among standards}

Comparing the load versus displacement/deflection results of these test methods indicates that FRCC materials can be classified differently depending on the test method used in the assessment. Table 6 shows that all test methods confirm that the investigated ECC material had a deflection hardening response, whereas, with regard to the SFRC material herein presented, various responses were found: deflection softening for ASTM C1609 and ASTM C1550 and almost perfectly plastic response according to EN 1465. 
Table 6. Comparison of standard test methods

\begin{tabular}{lllll}
\hline & ECC & & SFRC & \\
\cline { 2 - 5 } Test method & Classification & $\begin{array}{l}\text { Peak strength } \\
f_{\text {Peak }} \\
\mathrm{MPa}\end{array}$ & Classification & $\begin{array}{l}\text { Peak strength } \\
f_{\text {Peak }} \\
\mathrm{MPa}\end{array}$ \\
\hline $\begin{array}{l}\text { Three-point bending } \\
\text { (EN 14651) }\end{array}$ & $\begin{array}{l}\text { Deflection } \\
\text { hardening }\end{array}$ & 7.8 & $\begin{array}{l}\text { Almost } \\
\text { perfectly } \\
\text { plastic }\end{array}$ & 4.9 \\
$\begin{array}{l}\text { Four-point bending } \\
\text { (ASTM C1609) }\end{array}$ & $\begin{array}{l}\text { Deflection } \\
\text { hardening }\end{array}$ & 8.5 & $\begin{array}{l}\text { Deflection } \\
\text { softening }\end{array}$ & 4.4 \\
$\begin{array}{l}\text { RDP } \\
\text { (ASTM C1550) }\end{array}$ & $\begin{array}{l}\text { Deflection } \\
\text { hardening }\end{array}$ & 8.5 & $\begin{array}{l}\text { Deflection } \\
\text { softening }\end{array}$ & 5.4 \\
\hline
\end{tabular}

There is evidence that test results may significantly vary significantly due to a number of reasons, including details of the specimen preparation and casting method (fiber distribution and orientation) and the amount of friction to rotation and translation in the supports (especially for high deformation values) [26]. If the supports cannot freely rotate or accommodate a horizontal displacement, axial compressive stresses will be imposed on the cross-section of the beam, affecting the flexural behavior and the load-deformation response of the specimens. Other studies have shown that even careful control of specimen preparation cannot prevent non-uniform fiber distribution in the critical section between different specimens especially in softening materials with low volume fraction of fibers [9], resulting in a high variability of results. However, this study with higher fiber contents was able to obtain very consistent results also in beam tests.

It should be emphasized that the ability of the material to form multiple cracking under tensile loading is a property related to the fiber bridging stress-crack opening behavior. While this material property can be assessed by specific tensile tests as described in this paper, it naturally affects the behavior of the material in bending and will influence the results of flexural tests such as the beam or the plate test, which consequently will also experience multiple crack formation in flexure. 


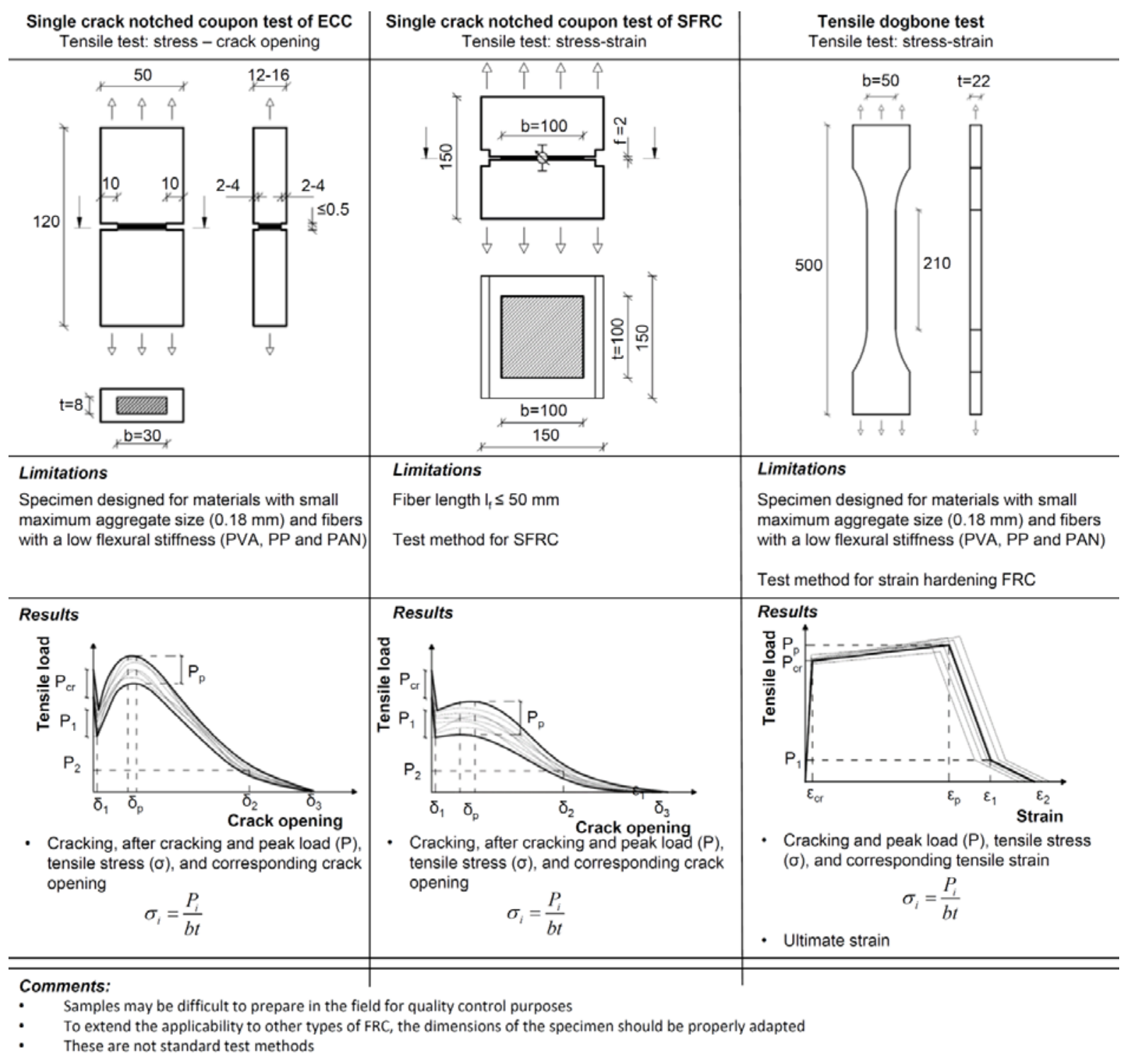

Figure 16. Summary of tensile tests 


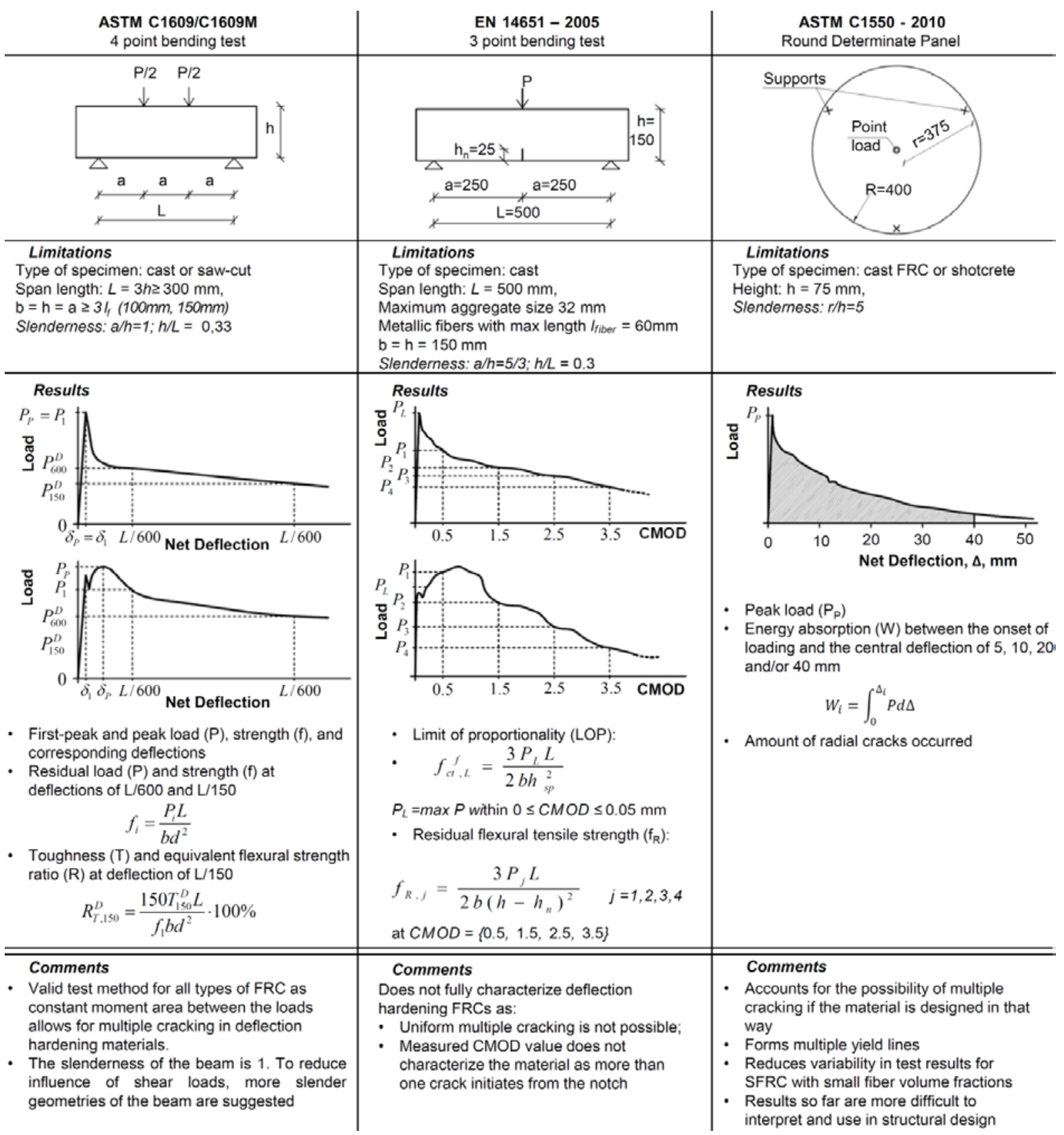

Figure 17. Summary of standardized test methods

The comparison of the results of 3PBT according to EN 14651 [5], 4PBT according to ASTM C1609 [6] and RDP tests according to ASTM C1550 [8] are summarized in Table 6. For strain hardening materials such as ECC, the lowest peak strength is determined 3PBT (7.8 $\mathrm{MPa}$ ) while the 4PBT and RDP tests showed almost identical results (8.5 MPa). This suggests that the 3PBT underestimates the properties of the ECC material in flexure as the crack formation in the notched beam is influenced not only by bending stresses but also by 
shear. For tension softening SFRC, the highest peak strength is determined by the RDP test (5.4 MPa) while the peak strength obtained from 3 and 4PBTs were 4.9 MPa and 4.4 MPa respectively.

Test procedures and the applicability of tensile and flexure test methods described in this paper are summarized in Figure 16 and Figure 17. The figures emphasize the test details, including test procedures, expression of results and the field of applicability; positive and critical aspects found; and limitations of each method. In particular, potential field application of the tensile test methods in Figure 16 is limited by the complicated test procedures and the need to customize the specimen geometry based on the fiber and aggregate dimensions.

\section{CONCLUSIONS}

Various test methods based on beams and plates in flexure were investigated in this study to assess their potential for determining the tensile properties of strain hardening and tension softening materials.

Based on the experimental results and discussion above, the following conclusions are drawn:

- While the tensile test methods provide the most straightforward analysis of test results, these methods have several explicit limitations that do not allow a broad application. The tensile tests are difficult to perform in standard concrete laboratories and require customization of specimen geometry based on the fiber and aggregate dimensions in the mixture design.

- The 3PBT with a notched beam specimen is not suitable for strain hardening materials as well as for some tension softening materials as diffuse cracking forms around the region of the notch as a result of disturbed stress regions (flexure and shear). This is primarily due to notch and loading point at mid-span. Moreover, the generated stress 
field is significantly disturbed on the whole sample and far from being flexuredominant.

- The 4PBT more realistically characterize the material, especially when the specimen geometry is slenderer. However, in commonly used 4PBTs the slenderness ratio a/h equals 1 and, therefore, the results are highly influenced by shear stresses. The authors recommend increasing the slenderness ratio a/h to 2 or higher to avoid this issue.

- A RDP test forces multiple crack lines to form. The plate specimen can be considered a slender bending specimen, where cracking is induced predominantly by bending stresses and not by shear stresses.

This study shows no significant reduction in variability of test results by using RDP test instead of 3 or 4PBT. Moreover, a RDP is almost three times heavier than that of a classical beam and the results of the RDP test are, at the moment, more difficult to interpret and use in structural design.

- In specifying the test method for characterization of the FRCC material, the specimen geometry shall be comparable to that of the actual structure: in particular, the thickness of the test specimen should be similar to that of the actual application, to promote similar fiber orientation and distribution. For materials designed to exhibit multiple cracking in the constant moment sections, this material performance property should be captured by the test.

As a general conclusion, envisaging future research, it can be certainly stated that to comply with previously mentioned requirements, to reduce the variability of test results and to minimize the influence of shear on the test results, a modified 4PBT could be developed that uses slender and wider beams (to increase the fracture area). Increasing the slenderness of the test specimen would ensure flexure-dominant state of stress. While this test setup would be suitable for any type of FRCC material, the optimal dimensions of the 
beam should be assigned as a function of fiber dimensions and type, maximum aggregate size and the structural application for which the material will be used.

\section{ACKNOWLEDGMENTS}

The authors would like to thank M.Sc. Francesco Nesi, M.Sc. Francesco Rosa, M.Sc.

Giovanni Crapiz, M.Sc. Silvia Finazzi and Daniela Bonfadini from the University of Brescia for their assistance in performing the experimental investigations presented herein.

Work presented herein was a part of Ieva Paegle's Ph.D. project funded by the Aase and Ejnar Danielsens Fond, the Knud Højgaards Fond, and the Technical University of Denmark. 


\section{REFERENCES}

1. Model Code 2010, “Final Complete Draft”, fib bulletins 65 and 66, March 2012-ISBN 978-2-88394-105-2 and April 2012-ISBN 978-2-88394-106-9 (2012).

2. Pereira, Eduardo B., Gregor Fischer, and Joaquim A. O. Barros. "Direct Assessment of Tensile Stress-Crack Opening Behavior of Strain Hardening Cementitious Composites (SHCC)”. CEMENT AND CONCRETE RESEARCH 42.6 (2012): 834-846. Web.

3. Larusson, L. H., Fischer, G., \& Jonsson, J. (2010). Mechanical interaction of Engineered Cementitious Composite (ECC) reinforced with Fiber Reinforced Polymer (FRP) rebar in tensile loading. In Advances in Cement-Based Materials - Proceedings of the International Conference on Advanced Concrete Materials (pp. 83-90). CRC Press.

4. Paegle, I., \& Fischer, G. (2013). Evaluation of test methods used to characterize fiber reinforced cementitious composites. In Proceedings of the International Conference: Innovative Materials, Structures and Technologies (pp. 122-128). Riga: RTU Press.

5. EN 14651 Test method for metallic fibre concrete - Measuring the flexural tensile strength (limit of proportionality (LOP), 2007.

6. ASTM C1609/C1609M-12 Standard Test Method for Flexural Performance of FiberReinforced Concrete (Using Beam With Third-Point Loading), 2012

7. Deutscher Ausschuss fur Stahlbeton, DafStb-Richtlinie Stahlfaserbeton (Guidelines for Steel Fiber Reinforced concrete), 2010. In German

8. ASTM C1550-10 Standard Test Method for Flexural Toughness of Fiber Reinforced Concrete (Using Centrally Loaded Round Panel), 2012. 
9. Minelli, F., Plizzari, G.A. 2011. New Round Panel Test for the Characterization of Fiber Reinforced Concrete: A Broad Experimental Study, Journal of testing and evaluation, 39: 889-897

10. GOM Optical Measuring Techniques, “Aramis v5.4 User Manual”, GOM mbH, (2005). www.gom.com

11. Pease, B.J., Geiker, M.R., Stang, H., Weiss, W.J. 2006. Photo-grammetric Assessment of Flexure Induced Cracking of Reinforced Concrete Beams under Service Loads, in Proc. of the 2nd Int. RILEM Symposium, Advances in Concrete through Science and Engineering, Québec City, Canada

12. ASTM C496 / C496M-11, Standard Test Method for Splitting Tensile Strength of Cylindrical Concrete Specimens

13. EN 12390-6:2009 Testing hardened concrete - Part 6: Tensile splitting strength of test specimens

14. Fischer, G.; Stang, H. and Dick-Nielsen, L. 2007. Initiation and development of cracking in ECC materials: Experimental observations and modeling, in Proceedings of the 6th International Conference on Fracture Mechanics of Concrete and Concrete Structures, 3: 1517-1522

15. RILEM TC 162-TDF: Vandewalle, L. et.al. 2002. Test and design methods for steel fibre reinforced concrete - Bending test, Materials and Structures, RILEM Publications, $35: 579-582$

16. JCI-S-002-2003 Method of test for load-displacement curve of fiber reinforced concrete by use of notched beam, Japan Concrete Institute Standard, 2003

17. EN 196-1:2005 Methods of testing cement. Determination of strength 
18. DBV-Guide to Good Practice. Steel Fibre Concrete. Editor: German Society for Concrete and Construction Technology, DBV, Berlin, 2001/2007

19. JCI-S-003-2007 Method of test for bending moment - curvature of FRCC, Japan Concrete Institute Standard, 2007

20. Johansen, K.W. 1962. Yield line theory, Cement and concrete association, London

21. Tran, Vng., Bernard, Es., \& Beasley, Aj. (2005). Constitutive modeling of fiber reinforced shotcrete panels. JOURNAL OF ENGINEERING MECHANICS-ASCE, 131(5), 512-521. doi:10.1061/(ASCE)0733-9399(2005)131:5(512)

22. Bernard, E. S. Development of a 1200-mm-Diameter Round Panel Test for Post-Crack Assessment of Fiber-Reinforced Concrete Advances in Civil Engineering Materials, 2013, 2, 457-471

23. Li, Victor C.; Kanda, T. (1998), 'Engineered Cementitious Composites for structural applications', Journal of Materials in Civil Engineering 10, 66-69.

24. Schlaich, J., Schafer, K., and Jennewein, M., 1987. Toward a Consistent Design of Structural Concrete. Journal, Prestressed Concrete institute, V. 32, No 3, May-June 1987, pp. 74-150.

25. Minelli, F., Plizzari, G., 2015. Derivation of a simplified stress-crack width law for Fiber Reinforced Concrete through a revised round panel test. Cement and Concrete Composites 58, 95-104.

26. Wille, K., \& Parra-Montesinos, G. J. (2012). Effect of Beam Size, Casting Method, and Support Conditions on Flexural Behavior of Ultra-High-Performance Fiber-Reinforced Concrete. ACI MATERIALS JOURNAL, 109(3), 379-388. 


\section{TABLES AND FIGURES}

\section{List of Tables:}

Table 1. Properties of fibers

Table 2. Properties of tensile specimens

Table 3. Properties of beam specimens

Table 4. Properties of RDPs

Table 5. Overview of statistical evaluation of test results

Table 6. Comparison of standard test methods

\section{List of Figures:}

Figure 1. Illustration of crack deformations: (a) illustration from DIC software; (b) schematic definition of opening

Figure 2. Single-crack notched coupon test of ECC: (a) specimen geometry; (b) test setup;

(c) specimen after testing

Figure 3. Single-crack notched coupon test of SFRC: (a) specimen geometry; (b) test setup.

Figure 4. Tensile dogbone test: (a) specimen geometry; (b) test setup

Figure 5. Notched 3PBT: (a) specimen geometry; (b) test setup with measuring devices.

Figure 6. 4PBT: (a) specimen geometry; (b) test setup with measuring devices.

Figure 7. RDP: (a) specimen geometry (top view); (b) test setup (side view)

Figure 8. Tensile stress-crack opening relationships: (a) of ECC and (b) of SFRC

Figure 9. Tensile properties of ECC

Figure 10. Load - CMOD relationships of three-point bending beams: (a) 3P-ECC-4150; (b) 3P-ECC-40; and (c) 3P-SFRC-150; (d) comparison between 3P-ECC-40 and 3P-ECC-150 
Figure 11. Crack distribution of FRCC beams under three-point bending: a) 3P-ECC-40 at peak, b) 3P-ECC-150 at peak, c) 3P-SFRC-150 at peak and d) 3P-SFRC-150 at CMOD of 1 $\mathrm{mm}$

Figure 12. Load - mid-span deflection relationships of four-point bending beams

Figure 13. Typical crack patterns at peak load: (a) 4P-ECC-50; (b) 4P-ECC -75; (c) 4P-ECC -150 and (d) SFRC beam

Figure 14. Load - deflection curves of RDPs.

Figure 15. Crack patterns of typical round panels specimen: P-ECC-75 (a) (b) (c); P-SFRC75 (d) (e) (f).

Figure 16. Summary of tensile tests

Figure 17. Summary of standardized test methods 